ANA PAULA MACEDO RUGGIERO

Métodos moleculares aplicados ao diagnóstico da tuberculose bovina 


\section{Métodos moleculares aplicados ao diagnóstico da}

\section{tuberculose bovina}

Dissertação apresentada ao Programa de PósGraduação em Epidemiologia Experimental e Aplicada às Zoonoses da Faculdade de Medicina Veterinária e Zootecnia da Universidade de São Paulo para obtenção do título de mestre em Medicina Veterinária

\section{Departamento:}

Medicina Veterinária Preventiva e Saúde Animal

Área de concentração:

Epidemiologia Experimental e Aplicada às Zoonoses

Orientador:

Profa. Dra. Eliana Roxo

São Paulo

2004 
Autorizo a reprodução parcial ou total desta obra, para fins acadêmicos, desde que citada a fonte.

DADOS INTERNACIONAIS DE CATALOGAÇÃO-NA-PUBLICAÇÃO

(Biblioteca da Faculdade de Medicina Veterinária e Zootecnia da Universidade de São Paulo)

T.1359 Ruggiero, Ana Paula Macedo

FMVZ Métodos moleculares aplicados ao diagnóstico da tuberculose bovina / Ana Paula Macedo Ruggiero. - São Paulo : A. P. M. Ruggiero, 2004.

$68 \mathrm{f}$.

Dissertação (mestrado) - Universidade de São Paulo. Faculdade de Medicina Veterinária e Zootecnia. Departamento de Medicina Veterinária Preventiva e Saúde Animal, 2004.

Programa de Pós-graduação: Epidemiologia Experimental e Aplicada às Zoonoses.

Área de concentração: Epidemiologia Experimental e Aplicada às Zoonoses.

Orientador: Profa. Dra. Eliana Roxo.

1. PCR. 2. Tuberculose bovina. 3ycobacterium bovis. 4. Diagnóstico. 5. Reação de polimerase em cadeia. 6. Métodos moleculares. I. Título. 


\section{FOLHA DE AVALIAÇÃO}

Nome do autor: RUGGIERO, Ana Paula Macedo

Título: Métodos moleculares aplicados ao diagnóstico da tuberculose bovina

Dissertação apresentada ao Programa de Pós-graduação em Epidemiologia Experimental e Aplicada às Zoonoses da Faculdade de Medicina Veterinária e Zootecnia da Universidade de São Paulo para obtenção do título de Mestre em Medicina Veterinária

Data:

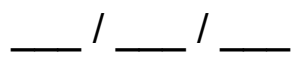

Banca Examinadora

Prof. Dr.

Instituição:

Assinatura:

Julgamento:

Prof. Dr.

Instituição:

Assinatura:

Julgamento:

Prof. Dr.

Instituição:

Assinatura:

Julgamento: 
DEDICATÓRIA 
Á meus pais Gilberto e Clara pela confiança, amor e dedicação durante todos estes anos. 
À minha irmã Patrícia pelo apoio e incentivo durante esta etapa. 
À meus irmãos Marcelo e Priscila e a toda minha família pela compreensão e interesse. 
AGRADECIMENTOS 


\section{AGRADECIMENTOS}

À Deus por permitir a conclusão desta etapa em minha vida e por atender á todas as minhas orações (que não foram poucas).

A Dra. Eliana Roxo, por ter aceitado ser minha orientadora, e acreditado que seríamos capazes apesar de todas as adversidades. Por todo o aprendizado, pela amizade, e por ser muitas vezes além de orientadora, mãe, amiga, e companheira.

A Prof Dra Sonia Regina Pinheiro pela colaboração e sugestões na conclusão deste trabalho.

Ao Prof Dr Silvio de Arruda Vasconcellos, pelo aprendizado imensurável.

Ao Prof. Dr José De Angelis Cortês por me apresentar ao fascinante mundo da epidemiologia.

A Dra Lucia Baldassi, pelo apoio e as boas conversas no laboratório.

A Dra Vera C. A. Ferreira e ao Dr Ricardo Harakawa do Instituto Biológico, pela paciência e dedicação em me ensinar e solucionar "problemões".

A Alice A. Ikuno, do Instituto Biológico por ter acreditado e colaborado muito para que o Laboratório de Biologia Molecular fosse real. 
A Prof Dra Clarice Queico F. Leite, da UNESP de Araraquara pelo estágio e por simplificar a biologia molecular.

Ao Dr. Sidney M. Sakamoto pelas valiosas sugestões.

À minhas amigas de peripécias laboratorias : Michelle, Helena, Martha e Juliana.

Á todos os estagiários e pesquisadores que me ajudaram durante estes três anos no Instituto Biológico.

À todos os pós graduandos e funcionários do VPS que sempre estavam dispostos a colaborar qualquer que fosse a situação.

Aos meus amigos pelas palavras de incentivo e por não me deixar desanimar.

À minha família por entender muitas das minhas ausências.

E a todas as pessoas que fizeram parte desta etapa da minha vida, por semanas, meses ou até anos e que com algumas palavras e estímulos me ajudaram a chegar até aqui. 


\section{RESUMO}

RUGGIERO, A. P. M. Métodos moleculares aplicados ao diagnóstico da tuberculose bovina. [Molecular methods applied to the bovine tuberculosis diagnosis]. 2004. $68 \mathrm{f}$. Dissertação (Mestrado em Medicina Veterinária) - Faculdade de Medicina Veterinária e Zootecnia, Universidade de São Paulo, 2004.

A tuberculose é uma das principais preocupações da Organização Mundial da Saúde, principalmente após o surgimento da AIDS que alavancou os índices da doença, sendo considerada a principal causa de morte por um único agente. Além do M. tuberculosis, agente responsável pela doença em humanos, outra manifestação importante é a tuberculose em bovinos causada pelo M. bovis, que também apresenta importância epidemiológica, devido à transmissão para o homem pela ingestão de alimentos contaminados, e a escassez de dados com relação à sua prevalência na população. Programas de controle da doença nos rebanhos bovinos existem em todo o mundo, e os maiores índices da doença encontram-se nos países em desenvolvimento. Estes programas estão baseados na identificação dos animais positivos, por meio de testes de tuberculina e sacrifício dos mesmos. Lesões encontradas em exames post-mortem podem ser submetidas a estudos bacteriológicos para o isolamento e identificação do agente e histopatológicos para a caracterização da lesão, os quais demandam meses para a sua conclusão. Com o advento da biologia molecular, novos métodos são propostos para a diminuir o tempo do diagnóstico de meses para poucos dias. Com o intuito de proporcionar um panorama das novas metodologias moleculares, como a técnica de PCR, empregadas no diagnóstico da tuberculose bovina, realizou-se uma revisão bibliográfica, apresentando as vantagens e dificuldades das mesmas. Apesar dos avanços alcançados com estas técnicas, a padronização de métodos viáveis para a rotina de diagnóstico laboratorial ainda não foi obtida, sendo essencial o investimento em pesquisas com o objetivo de solucionar estas barreiras.

Palavras-chave: Tuberculose bovina. Mycobacterium bovis. Reação em cadeia da polimerase. PCR. Diagnóstico. Métodos moleculares. 


\begin{abstract}
RUGGIERO, A. P. M. Molecular methods applied to the bovine tuberculosis diagnosis. [Métodos moleculares aplicados ao diagnóstico da tuberculose bovina]. 2004. $68 \mathrm{f}$. Dissertação (Mestrado em Medicina Veterinária) - Faculdade de Medicina Veterinária e Zootecnia, Universidade de São Paulo, 2004.
\end{abstract}

Tuberculosis is one of the main concern of World Health Organization, especially after the appearance of the AIDS that increased the rate of this disease that is the principal cause of death by one unique agent. Besides the tuberculosis caused by M. tuberculosis in human being, the disease caused by M. bovis in man shows epidemiological importance by its transmission trough contaminated food and the requirement of datas about its prevalence in human being. Control programs of bovine tuberculosis are present worldwide and the major rates of the disease are found in developing countries. This programs are based on test-and-slaughter, defined by the application of tuberculin test to cattle and slaughter of positive animals. Tuberculous lesions founded at post mortem inspection can be analyzed by bacteriological methods for isolation and identifying of the agent and histopathological examination that both require several days to conclusion. After the advent of molecular biology, new methods have been proposed to reduce the time of diagnostic from moths to few days. With the meaning to provide an overview of the new molecular methods applied to the bovine tuberculosis diagnosis, as PCR method, a review as carried out showing those advantages and difficulties. Although the advances reached by these techniques, the standardization of viable methods to the routine laboratory diagnosis couldn't be reached and the investment in researches is essential to solve these barriers.

Key words: Bovine Tuberculosis. Mycobacterium bovis. Polimerase chain reaction. PCR. Diagnosis. Molecular methods. 


\section{LISTA DE SÍMBOLOS E ABREVIATURAS}

a.C: antes de Cristo

d.C: depois de Cristo

AIDS: Síndrome da imunodeficiência adquirida

BCG: Bacille-Calmette-Guerin

DNA: ácido desoxirribonucléico

DR: região de repetição direta-Direct Repeat

DOTS: tratamento diretamente observado -direct observed treatment

HIV:Vírus da síndrome da imunodeficiência adquirida

hsp: proteína de choque térmico - heat shock protein

IS: seqüência de inserção

KDa: kilo Daltons

ml:mililitro

M. africanum: Mycobacterium africanum

M. avium:Mycobacterium avium

M. bovis : Mycobacterium bovis

M. intracellulare: Mycobacterium intracellulare

M. microti: Mycobacterium microti

M. scrofulaceum: Mycobacterium scrofulaceum

M. tuberculosis : Mycobacterium tuberculosis

MDR: muti-droga resistente 


\section{LISTA DE SÍMBOLOS E ABREVIATURAS}

MOOT: micobactéria não tuberculosa - mycobacteria other than tubercle bacilli

MAC: complexo Mycobacterium avium

MAIS: complexo Mycobacterium avium-intracellulare e scrofulaceum

$\mu \mathrm{m}$ : micrometro

$\mu \mathrm{g}$ : micrograma

OMS: Organização Mundial da Saúde

OPS: Organização Panamericana da Saúde

PCR: Reação de Polimerase em Cadeia

PFGE: Pulsed Field Gel Electrophoresis

PRA: PCR com análise de restrição

UFC: Unidade formadora de colônia

$\%$ : porcentagem

${ }^{\circ} \mathrm{C}$ : graus Celsius 


\section{SUMÁRIO}

Página

AGENTE $-18$

A HISTÓRIA DA DOENÇA

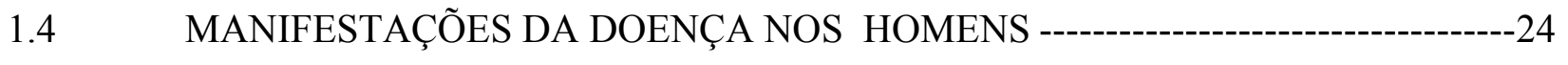

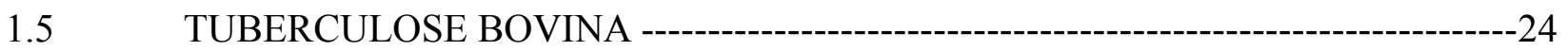

1.6 TUBERCULOSE EM HUMANOS DEVIDO AO M. BOVIS -------------------------25

1.7 OCORRÊNCIA DE TUBERCULOSE BOVINA --------------------------------------27

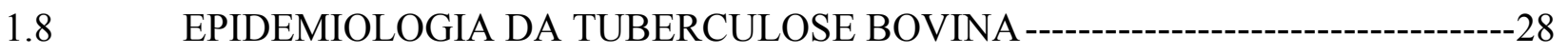

1.9 PERDAS ECONÔMICAS --------------------------------------------------------------------29

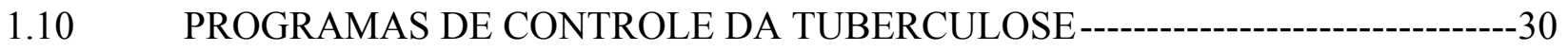

1.11 PROGRAMAS DE CONTROLE DA DOENÇA NA AMÉRICA DO SUL------------31

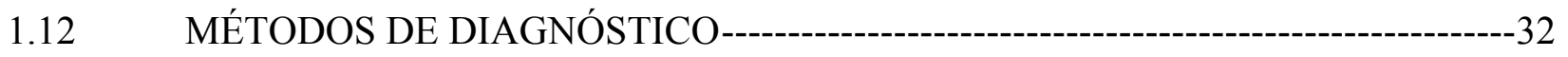

1.13 DIAGNÓSTICOS MOLECULARES ------------------------------------------------------34

OBJETIVOS -----------------------------------------------------------------------------------36

3.1 O EMPREGO DA PCR PARA DETECTAR TUBERCULOSE ANIMAL ----------38

3.2 PRIMERS OU OLIGONUCLEOTÍDEOS PARA O MÉTODO DE PCR -------------39

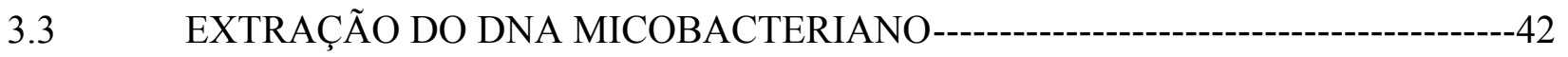

3.4 MÉTODOS DE EXTRAÇÃO DE DNA DE M. BOVIS ------------------------------44

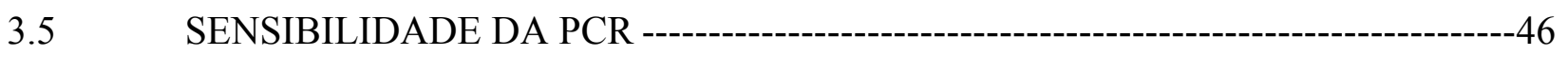

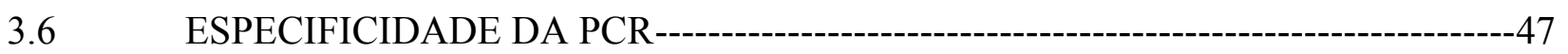

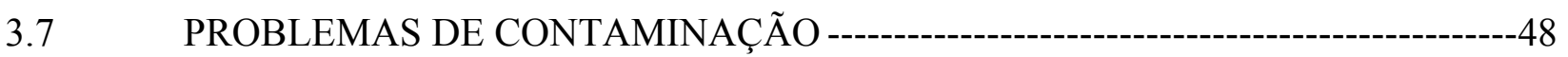




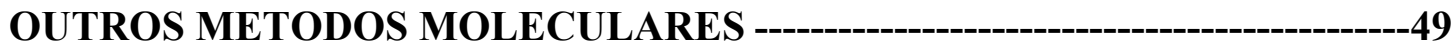

4.1 SEPARAÇÃO DE MOLÉCULAS POR ELETROFORESE----------------------------49

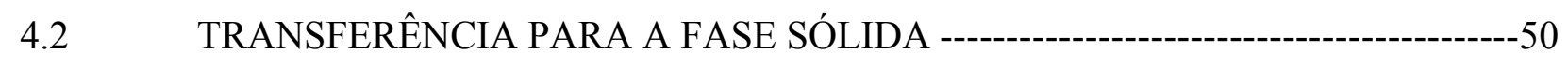

4.3 RFLP (RESTRICTION FRAGMENT LENGTH POLYMORPHISM)-------------------50

4.4 PFGE (PULSED FIELD GEL ELETROPHORESIS) --------------------------------52

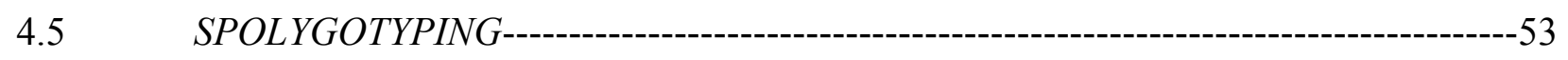

4.6 PRA (PCR COM ANÁLISE DE RESTRIÇÃO)-----------------------------------------55

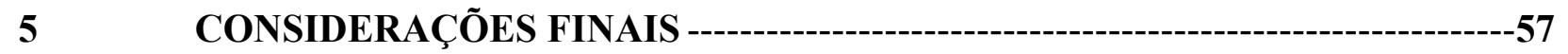

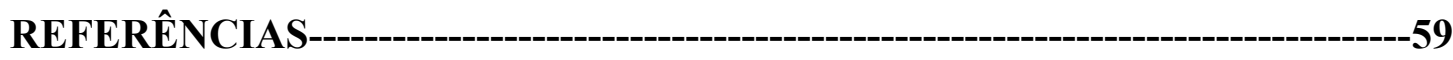


A tuberculose é uma doença considerada em sua essência uma "epidemia lenta", uma das últimas pestes que assolaram a humanidade (peste branca) e que ressurge nos dias de hoje como uma "emergência global", sendo a principal causa de morte provocada por um único agente. A estimativa para este século, entre os anos de 2000 a 2020, é de que aproximadamente um bilhão de pessoas estarão infectadas por esta doença; destas, 200 milhões de pessoas ficarão doentes e 35 milhões irão morrer de tuberculose, caso o controle não seja eficiente e rígido (PAULA, 1988; WORLD HEALTH ORGANIZATION, 1994; WORLD HEALTH ORGANIZATION,2004).

\subsection{AGENTE}

A doença é provocada por bacilos imóveis, não esporulados, aeróbios, não capsulados e não flagelados, medindo de 0,3 a $0,6 \mu \mathrm{m}$ de largura por 1 a $4 \mu \mathrm{m}$ de comprimento e sendo também álcool-ácidos resistentes, isto é quando corados a quente pela fucsina, resistem à descoloração com álcool-ácido. As micobactérias pertencem à ordem Actinomycetales, família Micobacteriaceae, gênero Mycobacterium, com mais de 70 espécies conhecidas. As principais espécies de importância epidemiológica para o homem estão no complexo M. tuberculosis, que inclui o M. tuberculosis, Mycobacterium bovis (M. bovis), o M. microti (patogênico apenas para a ratazana - Microtis agrestis),o M. africanum (ainda não isolada no Brasil) e o M. canettii, não patogênico para o homem (ABRAHÃO, 1998; BIER, 1978; BROSCH et al., 2002; CORNER, 1994). No ano de 2003, mais uma espécie foi descoberta, M. pinnipedii isolada em focas e leões marinhos, mas pouco se sabe sobre sua patogenicidade para homens e outros animais (COUSINS et al., 2003). 
Algumas micobactérias, excluindo as do complexo M. tuberculosis, também denominadas de MOOT (mycobacteria other than tubercle bacilli), e podendo receber entre as diversas designações entre as quais: micobactérias "atípicas", "anônimas", "não classificadas", "saprófitas", “oportunistas”, "não tuberculosas” e, mais atualmente, “ambientais". Essas micobactérias estão divididas em potencialmente patogênicas ou não patogênicas para o homem. Entre as patogênicas, destacam-se o M. avium e M. intracellulare, que não podem ser facilmente diferenciados através de testes de identificação rotineiros, e desta forma são cepas pertencentes ao complexo M. avium, MAC ou MAIS, se a estirpe M. scrofulaceum estiver incluída (HAAGSMA, 1995; KANTOR, 1979; KONEMAN et al., 1993; PRITCHARD, 1988).

\subsection{A HISTÓRIA DA DOENÇA}

Relatos da doença existem desde o período paleolítico e recentes descobertas revelam a presença de tuberculose óssea (mal de Pott) em um fóssil de bisão americano com mais de 17.000 anos, através da análise com a técnica de DNA. No exame realizado o DNA identificado neste fóssil era semelhante ao de amostras de Mycobacterium tuberculosis, mas com algumas seqüências a menos, que podem ter sido perdidas durante o processo evolutivo. Esses dados definiram uma nova hipótese a de que o M. bovis pode descender do M. tuberculosis ou de um ancestral comum (ROTHSCHILD et al., 2001).

Em 3.000 a.C, na dinastia de Ramsés II no Egito, foram encontradas múmias com vestígios de tuberculose. Descrições da doença, denominada anteriormente como "phthisis", ou tísica, foram feitas por Hipócrates na Grécia em 460 a.C. No Império Romano, a tuberculose descrita como "consuption" era uma doença caquetizante, incurável, e aos doentes recomendava-se descanso, boa alimentação e ar fresco. Em 1720, Sylvius de la Bol, na 
Holanda descreveu os tubérculos, as cavidades tuberculosas e os linfonodos tuberculosos. Em 1782, Leopold Avensbrugger publicou um livro sobre a relação entre as mudanças patológicas e os sinais clínicos da tuberculose. Durante a Revolução Industrial, inúmeros casos de tuberculose surgiram devido a aglomerações de trabalhadores, as condições de trabalho insalubres e desgastáveis e a qualidade de vida precária. No inicio do século XX, a doença desencadeava um terror coletivo na Europa, principalmente na primeira metade do século, onde o diagnóstico significava uma sentença de morte para 50\% dos doentes, na maioria crianças e jovens (SUCCI, 1976; PAULA, 1988; CORREA e CORREA, 1992; LONDON SCHOOL OF HYGIENE, 1994).

Em 1810, Carmichael observou uma ligação entre a escrófula em crianças e o consumo de leite de vaca, e conclui erroneamente que a doença era desencadeada por fatores nutricionais. Só em 1846, Klencke aproximou-se da verdade ao perceber que a freqüência de linfadenite tuberculosa era maior entre crianças alimentadas com leite de vaca do que as crianças alimentadas com leite materno, concluindo que o leite era a fonte de infecção da doença. No ano de 1865, Villemin, reproduziu experimentalmente a tuberculose, inoculando coelhos com material proveniente de vacas doentes. Observou também, que o material infectante proveniente de bovinos era mais virulento para os coelhos do que o material análogo proveniente de humanos, ressaltando o perigo do consumo do leite contaminado e a necessidade da inspeção veterinária de carcaças com lesões da tuberculose. Apenas em 1884, Robert Koch anunciou publicamente que havia observado, através de recursos tintoriais e cultivo em meio apropriado, o bacilo responsável pela doença do homem e dos bovinos, o que significou o grande divisor de águas na história da tuberculose. Koch denominou-o "Tuberkelbacillen" - bacilo da tuberculose. Zopf, no ano de1883, já havia proposto uma denominação para este agente: Bacterium tuberculosis ; apenas em 1986 Lehmann \& Neumann, incluíram-no como espécie do gênero Mycobacterium. Até o ano de 1970, o bacilo 
bovino foi considerado uma subespécie do M. tuberculosis sendo denominado de M. tuberculosis variante bovis, posteriormente Karlson e Lessel, propuseram classificá-lo como espécie M. bovis (FERREIRA NETO; BERNARDI, 2001).

No século XIX, havia a crença generalizada, compartilhada por Koch e outros autores, de que existia apenas um tipo de bacilo da tuberculose acometendo homens e animais.Em seu trabalho Koch afirma com base em suas observações ..."que em todas as condições de tuberculose do homem e dos animais existe uma bactéria característica que eu designei como bacilo da tuberculose, e que possui propriedades específicas que permitem distingui-lo de todos os outros microorganismos conhecidos"... Poucos autores se atreviam a discordar dessa idéia, tamanho o prestígio e credibilidade de Koch na época. Mas em 1897, Smith observou que o bacilo da tuberculose encontrado nos bovinos era diferente do bacilo proveniente dos humanos: era menor, reduzia a acidez do meio de cultura, apresentava crescimento mais lento e com menor vigor que o bacilo oriundo do homem. Lançando dúvidas sobre a teoria da existência de um único bacilo, Smith também verificou que o bacilo dos bovinos era mais virulento para os animais de laboratório, especialmente coelhos, declarando então ..."se o bacilo bovino pode invadir o corpo humano sem permissão ou obstáculo, não temos que nos proteger apenas da infecção alimentar através do leite e produtos lácteos, como também da doença por inalação, a qual o homem está exposto nos estábulos que contenham gado tuberculoso"... (ABRAHÃO,1998; KOCH, 1882; PRITCHARD,1988; TÖRNING, 1965).

No inicio do século XX, as dúvidas sobre a doença tanto no homem como no animal, principalmente relacionada ao possível potencial zoonótico da tuberculose bovina, eram inúmeras, e o governo inglês nomeou uma comissão para estudar o assunto, criando a "Royal Commission on Tuberculosis", desenvolvendo um extenso programa de pesquisa, com o objetivo de esclarecer definitivamente as dúvidas sobre a natureza da tuberculose bovina e sua 
relação com a tuberculose humana. Em 1911, chegou-se a conclusão definitiva de que bovinos tuberculosos representavam um risco para a saúde pública e algo precisava ser feito, já que os dados da ocorrência da doença nos animais eram alarmantes (FERREIRA NETO; BERNARDI, 2001).

\subsection{PANORAMA ATUAL DA DOENÇA}

A tuberculose na década de 90 foi um dos maiores problemas de saúde pública nos países em desenvolvimento. Nas Filipinas, foi a segunda causa de morte. Na Índia, América Latina e África, os índices de prevalência são altíssimos. Na Europa, foram registrados em 1995, cerca de 280.000 casos de tuberculose, aumentando para quase 370.000 em 2000. Neste ano, quase $70 \%$ dos casos reportados ocorreram nos países do leste europeu que pertenciam à União Soviética. A doença afeta principalmente, homens jovens, presídios masculinos, alcoólatras, e outras pessoas com desvantagens sociais. O declínio da infra-estrutura de saúde pública e a deterioração das condições de vida nesses países são os principais motivos para o aumento da doença (O’REILY et al., 1989; WORLD HEALTH ORGANIZATION, 1993; WORLD HEALTH ORGANIZATION REGIONAL OFFICE FOR EUROPE, 2002).

Na década de 70, a diminuição da imunidade já era considerada um fator de extrema importância para o aumento do número de casos da doença (SUCCI, 1976). O aparecimento da síndrome de imunodeficiência adquirida (AIDS) em humanos, na década de 80, alavancou o número de casos de tuberculose, e segundo projeções do final do século $\mathrm{XX}$ aproximadamente $9,0 \%$ dos novos casos seriam atribuídos ao vírus imunossupressor (HIV), sendo o principal agente o M. tuberculosis como possivelmente o M. bovis (O'REILY et al, 1989; WORLD HEALTH ORGANIZATION, 1993). 
Em países desenvolvidos, como os do oeste europeu, os índices de tuberculose encontram-se elevados principalmente em usuários de drogas, imigrantes e pessoas idosas. Nestes países, as pessoas com HIV são consideradas um grupo de risco especial. A epidemia de AIDS é uma das maiores causas da expansão da tuberculose no mundo. Cerca de um terço dos pacientes com AIDS morre de tuberculose (WORLD HEALTH ORGANIZATION REGIONAL OFFICE FOR EUROPE, 2002).

Um dos maiores problemas da doença atualmente é o aparecimento de cepas multi-droga resistentes (MDR), que limitam ainda mais as opções de tratamento. O principal motivo para o aumento de casos de tuberculose multi-droga resistente é a interrupção do tratamento convencional, devido à melhora do quadro clínico nos primeiros meses do tratamento, e a carência de medicamentos em alguns países (WORLD HEALTH ORGANIZATION, 2004).

Com o intuito de conter o avanço da tuberculose, a Organização Mundial de Saúde (OMS) junto com os seus parceiros internacionais criaram um protocolo de tratamento, no qual os pacientes com a doença são monitorados pelo agente de saúde ou por voluntários que fiscalizam a terapia. A finalidade deste programa é garantir que os pacientes não interrompam o tratamento ao apresentar melhora dos sintomas, e garantir que em países com poucos recursos não falte medicamentos durante o tratamento. Este programa tem apresentado bons resultados, principalmente nos países onde os serviços públicos de saúde encontram-se em dificuldade. O programa recebe o nome de DOTS (Direct Observed Treatments) (WORLD HEALTH ORGANIZATION, 1998; WORLD HEALTH ORGANIZATION, 2004). 


\subsection{MANIFESTAÇÕES DA DOENÇA NO HOMEM}

A principal manifestação da tuberculose humana causada pelo M. tuberculosis é a tuberculose pulmonar, com $90 \%$ dos casos. O primeiro contato com a doença é denominado de primo-infecção, sendo comum na infância e na maioria das vezes o organismo consegue reagir a este primeiro contato, e os sintomas são semelhantes a um resfriado, a melhora clínica ocorre após 2 semanas, sendo o indivíduo denominado de infectado. A transmissão da doença ocorre quando um indivíduo com tuberculose pulmonar e bacilífera, com exame de escarro positivo, ao tossir, espirrar ou falar, elimina bacilos no ar e são aspirados por outro indivíduo. Os principais sintomas e sinais da forma pulmonar são: tosse persistente por mais de três semanas, normalmente com expectoração, cansaço, febre vespertina, sudorese noturna, perda de apetite, emagrecimento e hemoptise (SECRETÁRIA DE ESTADO DE SAÚDE DO RIO DE JANEIRO, 2004; SOUZA, 2003; WORLD HEALTH ORGANIZATION, 1994).

Outras formas de tuberculose podem ocorrer sendo denominadas de tuberculose extrapulmonar, por acometerem outros órgãos, entre eles: meninges, pleura, rins, linfonodos, pele, globo ocular, aparelho genital, digestivo, estruturas ósseas entre outros, representando até $18 \%$ do total de casos notificados As formas extra-pulmomares mais freqüentes são a pleural (que ocorre por ruptura de pequenos focos pulmonares subpleurais) em 45\%, a linfática 15\%, gênito-urinária 16\%, miliar (disseminação por ruptura de lesão dentro de um vaso sanguíneo com disseminação dos bacilos por todo organismo) em $10 \%$ e a osteo-articular $7 \%$ (SECRETÁRIA DE ESTADO DE SAÚDE DO RIO DE JANEIRO, 2004; SOUZA, 2003; WORLD HEALTH ORGANIZATION, 1994). 


\subsection{TUBERCULOSE BOVINA}

Assim como a tuberculose humana, a tuberculose bovina possui distribuição cosmopolita e volta a assumir grande importância em todo o mundo, e novamente nos países em desenvolvimento, com índices alarmantes (KANTOR; RITACCO, 1994).

A tuberculose bovina é uma zoonose, causada pelo M. bovis, cujo hospedeiro primário é o bovino. Caracteriza-se pela formação de granulomas nodulares, conhecidos como tubérculos. Embora seja definida como uma doença infecciosa com evolução crônica e efeito debilitante, pode ocasionalmente assumir um caráter agudo e curso progressivo rápido. Diversas espécies de mamíferos, incluindo o homem, são susceptíveis ao bacilo bovino (CENTRO PANAMERICANO DE ZOONOSIS, 1988; HAAGSMA, 1995).

A tuberculose em bovinos na forma pulmonar foi primeiramente descrita por Columela, em 40 DC. Até o final do século XVII, a tuberculose miliar ou de pequenos nódulos, conhecido como o "mal perolado" das membranas serosas e era considerado como uma forma de sífilis transmitida por pessoas doentes ao manter relações zooerrásticas com animais (BEER, 1981).

A luta contra a tuberculose bovina teve sua origem no início do século XIX, quando se provou definitivamente sua transmissibilidade para o ser humano, através do leite infectado (GRANGE, J. M.; YATES,M.D, 1994).

\subsection{TUBERCULOSE EM HUMANOS DEVIDO AO M. BOVIS}

Registros sobre tuberculose causada pelo M. bovis em humanos são escassos, principalmente na América Latina e Caribe, decorrente da metodologia empregada para o diagnóstico da doença, a baciloscopia do escarro, que é ineficaz para distinguir o bacilo 
humano do bovino. Na América Latina estimações conservadoras indicam que do total dos casos em humanos cerca de $2 \%$ dos quadros pulmonares e $8 \%$ dos casos extrapulmonares têm como agente o M. bovis. (KANTOR; RITACCO, 1994; LATINI et al., 1990; USABIAGA, 2001).

Nos países onde o controle da tuberculose bovina não existe, a doença causada pelo M. bovis ocorre principalmente em pessoas jovens pela ingestão e manipulação de leite contaminado. No século XX, jovens e crianças eram considerados mais sensíveis à infecção por M. bovis. Pesquisadores afirmavam que a incidência de tuberculose em criança era igual à tuberculose em bovinos. As principais formas de ocorrência da doença eram lesões intestinais, escrofulose (ou linfadenopatia cervical), e outras lesões não pulmonares. Calculava-se que, no inicio do século, 70 a $80 \%$ dos casos de tuberculose dos gânglios cervicais em crianças e $20 \%$ dos casos de tuberculose renal em homens eram causados por $M$. bovis. Trabalhadores rurais ou que mantenham maior contato com animais infectados, podiam adquirir a forma pulmonar ao inalar aerossóis. A reativação endógena de infecções adquiridas na infância ou na juventude representa a causa mais comum de tuberculose humana por M. bovis, principalmente na Europa, atualmente (HARDIE; WATSON, 1992; KLEEBERG, 1984; NEIL et al., 1992, WEISNER, 1973).

Relatos de tuberculose zoonótica nos países em desenvolvimento e desenvolvidos são escassos. No inicio do século XX, a infecção humana por M. bovis era estimada entre 10 a $18 \%$ de todos os casos de tuberculose, e com uma relação estreita entre o número de doentes identificados e a prevalência da doença na população bovina local (DABORN et al., 1996; SAURET et al., 1992).

Estudos realizados em vários países no período de 1954 a 1970 estimaram que do total dos casos de tuberculose humana, 3,1\% eram causados por M. bovis, sendo este agente 
responsável por 2,1\% dos casos de tuberculose pulmonar e 9,4\% dos casos de tuberculose extrapulmonar (GERVOIS et al.,1972).

Em países como a Argentina, que possui recursos para o diagnóstico bacteriológico, através de isolamento e identificação do agente, ficou comprovado que a doença causada pelo Mycobacterium bovis apresenta um caráter basicamente profissional, e sua transmissão ocorre através de aerossóis. Durante os anos de 1984 a 1989, de todos os casos de tuberculose diagnosticados, $2,4 \%$ a $6,2 \%$ eram causados pelo bacilo bovino, e cerca de $64 \%$ envolviam profissionais de matadouros e tratadores de animais. Em países desenvolvidos como os Estados Unidos, estima-se que no Estado da Califórnia, em 2001, cerca de 7\% dos casos de tuberculose humana, sejam causados por M. bovis (KANTOR ; RITACCO, 1994; LATINI et al., 1990; USABIAGA, 2001).

\subsection{OCORRÊNCIA DE TUBERCULOSE BOVINA}

A ocorrência de tuberculose bovina no Brasil, com uma população estimada em 1986, de 137 milhões de cabeças de gado estavam entre 0,9 a 2,9\% com $6,2 \%$ a $26,3 \%$ dos rebanhos acometidos. Neste mesmo ano, a taxa de lesões tuberculosas encontradas em matadouros foi de $0,14 \%$ (KANTOR, 1988; KANTOR; RITACCO, 1994). No período de 1989 a 1998, os dados de notificações oficiais da doença indicavam uma prevalência média nacional de 1,3\% de animais infectados. Um levantamento realizado em 1999, no Triângulo Mineiro e nas regiões do centro e sul de Minas Gerais, envolvendo aproximadamente 1.600 propriedades e 23.000 animais, estimou a prevalência aparente de animais infectados em $0,8 \%$. No mesmo estudo foram detectadas $5 \%$ propriedades com animais reagentes, sendo importante destacar que este valor subiu a $15 \%$ no universo de propriedades produtoras de leite com algum grau 
de mecanização da ordenha e de tecnificação da produção (MINISTÉRIO DA AGRICULTURA, PECUÁRIA E DO ABASTECIMENTO, 2004).

A Organização Panamericana de Saúde (OPS) classificou em 1995 os países em categorias, de acordo com o grau de prevalência da doença, sendo denominados países livres, aqueles com índices menores que $0,1 \%$, com $37,7 \%$ da população bovina estimada para as Américas, prevalências maiores que $0,1 \%$, na categoria seguinte, com $57,6 \%$ da população estimada, neste inclui-se o Brasil e a Argentina e na última categoria, países que desconhecem a situação nacional da doença ou apresentam dados antigos ou escassos (ORGANIZACION PANAMERICANA DE LA SALUD, 1995).

\subsection{EPIDEMIOLOGIA DA TUBERCULOSE BOVINA}

A tuberculose bovina é uma doença primordialmente respiratória com transmissão basicamente aerógena entre as espécies (MORRIS et al., 1994; O'REILLY; DABORN, 1995).

As rotas de infecção no gado são influenciadas por diversos fatores como idade, ambiente e praticas de higiene. Em animais jovens, a via digestiva pode ocorrer devido à ingestão de leite e colostro contaminados. Mas em países com programas de controle, e onde o gado tuberculoso é eliminado, animais com lesões intestinais são mais difíceis de serem encontrados. A transmissão aerógena tem maior probabilidade de ocorrer pela própria conduta natural do rebanho, especialmente em fazendas com alta densidade do rebanho, estabulação e pela venda ou troca de animais (NEILL et al., 1994).

Os animais infectados são a principal fonte de infecção, sendo a via orofaríngea a porta de entrada mais comum. Alimentos contaminados e pastos possuem menor importância na transmissão da doença. O bovino, uma vez infectado, é capaz de transmitir a doença para 
outros animais, antes mesmo de apresentar lesões teciduais (CORNER, 1994; KLEEBERG, 1984; MORRIS et al., 1994).

O agente pode ser eliminado por diversas vias como o ar expirado, corrimento nasal, leite, fezes, urina e secreções vaginais, uretrais e pelo sêmen. A transmissão placentária nos bovinos pode ser considerada rara ou inexistente. As vias de transmissão referidas com menor freqüência são a intra-uterina, o coito e a inseminação artificial, através do sêmen contaminado (NEIL et al., 1994; ROXO, 1995).

O estabelecimento da doença pode ser favorecido por fatores como má-nutrição, doenças intercorrentes, aumento da produção leiteira e gestação. No período inicial da infecção podem não haver sintomas, os sinais clínicos ocorrem em casos mais avançados e correspondem a emaciação gradual, aumento dos linfonodos e tosse. As lesões tuberculosas são mais freqüentemente encontradas nos pulmões, linfonodos retrofaríngeos, brônquicos, mediastínicos, mesentéricos, no fígado, baço e em outros órgãos. A lesão primária, ou foco da infecção é estabelecido durante a interação do hospedeiro e patógeno. O conjunto da lesão na porta de entrada do bacilo, mais a lesão do linfonodo primário denomina-se complexo primário (KLEEBERG, 1984; HAAGSMA, 1995; NEILL et al. 1994).

\subsection{PERDAS ECONÔMICAS}

As perdas econômicas estão relacionadas principalmente à baixa produtividade e a condenação de carcaças em matadouros. Um animal tuberculoso pode apresentar 10 a $25 \%$ de queda na capacidade produtiva, além de ser um foco da doença para outros animais, e o homem. Na Argentina em 1988, a perda com a produção leiteira oriunda de vacas tuberculosas foi de $18 \%$ com relação à primeira lactação e com decréscimo no número e na 
duração de lactação, quando comparadas com vacas sadias (KANTOR; RITACO, 1994; ROXO, 1996).

\subsection{PROGRAMAS DE CONTROLE DA TUBERCULOSE}

Programas de controle da doença nos rebanhos em países industrializados foram criados e implantados no inicio do século passado. Nos Estados Unidos o programa foi estabelecido em 1917, e o evento mais importante era a inspeção da carne em matadouros para detectar o gado tuberculoso. No Canadá o programa foi criado em 1923, mas a inspeção de carcaças já era realizada desde 1907 (ESSEY; KOLLER, 1994). No Brasil, o Regulamento de Inspeção de Produtos de Origem Animal - RISPOA, que inclui a classificação e disposição legal das carcaças com lesões sugestivas de tuberculose é datado de 1949.

Nos países onde foram adotados programas de controle da tuberculose bovina, demonstraram que doença é controlável e o rendimento financeiro não demora a aparecer, quando os recursos humanos e financeiros são adequados e a administração eficiente (CENTRO PANAMERICANO DE ZOONOSES, 1983; KLEEBERG, 1984).

Com a globalização dos mercados surgem novas exigências com relação à saúde animal, obrigando o estabelecimento e manutenção de áreas livres de enfermidades, com o objetivo de eliminá-las definitivamente e possibilitar a competitividade nos mercados mundiais (USABIAGA, 1995).

Para um sucesso nos programas de controle da tuberculose bovina existe a necessidade de um controle efetivo da doença, contando com a atuação do governo associado a testes sistemáticos dos animais, remoção e sacrifício dos infectados, prevenção da dispersão da doença e da introdução ou reintrodução da doença. A qualidade de todos os serviços 
envolvidos no diagnóstico da tuberculose é que garantem o objetivo do programa: erradicar a doença (CORNER et al., 1994; PRITCHARD, 1988).

A América Latina deve redobrar seus esforços para combater a tuberculose, estruturando seus planos de combate baseando-se em esquemas de regionalização, com estratégias de acordo com as condições culturais, geográficas, de infra-estrutura, economia e sistema de produção de cada região (USABIAGA, 2001).

\subsection{PROGRAMAS DE CONTROLE DA DOENÇA NA AMÉRICA DO SUL}

A Argentina iniciou o seu programa de controle da doença em 1993; estimativas de prevalência nacional são poucas e determinadas através de levantamentos realizados em províncias leiteiras de maior importância, como Santa Fé. Em 2002, indicavam uma prevalência de 7,74 \% de infecção detectada, sendo superior aos dados divulgados por Latini e colaboradores em 1997, na ordem de 5,6\% de animais reagentes ao teste tuberculínico, e semelhantes aos resultados do único levantamento nacional realizado em 1971, com 8\% de animais (ABDALA, 2003).

No Brasil, o Programa Nacional de Controle e Erradicação de Brucelose e Tuberculose foi lançado oficialmente em 10 de janeiro de 2001, e esta em fase de implantação. O programa tem como objetivo baixar a prevalência e a incidência de tuberculose e brucelose no país, através do diagnóstico dos animais positivos e sacrifícios dos mesmos e incentivar a certificação de rebanhos livres da doença. Inicialmente a adesão ao programa será voluntária, podendo refletir em benefícios aos produtores, nos valores dos produtos certificados (MINISTÉRIO DA AGRICULTURA, PECUÁRIA E DO ABASTECIMENTO, 2004). 


\subsection{MÉTODOS DE DIAGNÓSTICO}

Em bovinos, o método de diagnostico in vivo preconizado é o teste tuberculínico, que consiste em provas cutâneas indiretas, uma vez que o diagnóstico clínico da doença é muito difícil, e os sintomas podem não estar presentes em infecções recentes (CENTRO PANAMERICAO DE ZOONOSIS, 1988; HAAGSMA, 1995). No exame post mortem, estudos bacteriológicos e histopatológicos das lesões macroscópicas permitem controlar o diagnóstico realizado a campo e permitem avaliar a eficácia das provas tuberculínicas (CENTRO PANAMERICANO DE ZOONOSIS, 1988; ORGANIZACIÓN PANAMERICANA DE LA SALUD, 1995).

Alguns animais, ainda que infectados, não respondem aos testes cutâneos tuberculínicos, fenômeno denominado de anergia (caracterizado pela ausência de reatividade cutânea) e pode ocasionar resultados falsos negativos (MONAGHAN et al., 1994).

Entre os principais fatores de ocorrência de falsos negativos destacam-se: infecção recente, final de gestação, parto, desnutrição, animais em estado avançado da doença e o uso inadequado de drogas imunossupressoras. Resultados falso-negativos podem ocorrer por variações inerentes ao próprio teste ou por variações na sua leitura e interpretação (MONOGHAN et al., 1994; O’REILLY; DABORN, 1995).

Reações inespecíficas provenientes de reatividade cruzada com micobactérias atípicas, M. paratuberculosis, M. avium, podem acontecer em animais tuberculinizados caracterizados como reatores, e que não são observadas lesões ao abate. Com o objetivo de confirmar a ocorrência de falsos positivos, a análise das carcaças dos animais, através de uma inspeção post-mortem muito minuciosa é imprescindível, mas que muitas vezes é impossível de ser realizada em matadouros (MONOGHAN et al., 1994; O’REILLY; DABORN, 1995). 
O teste de tuberculina em bovinos apresenta uma sensibilidade com variação entre 32 a $99 \%$ e uma especificidade de 75,5 a $99,9 \%$. Em estudos realizados, os animais reatores ao teste, cerca de $70 \%$ apresentavam lesões em pulmões, o que confirma a baixa sensibilidade do teste (O’REILLY et al., 1995; VITALE et al.,1998).

Os métodos histológicos, como de coloração, através de cortes de lesões coradas empregados para identificar os bacilos são rápidos e baratos, mas outros agentes que não o M. bovis podem produzir lesões semelhantes à da tuberculose bovina, dificultando o diagnóstico, além da exigência de grandes concentrações de bactéria para a realização do teste, cerca de $10^{4}$ bacilos por ml ou mais (HAAGSMA, 1995; WARDS et al., 1995; ZANINI et al., 2001).

O diagnóstico definitivo da doença baseia-se no isolamento e identificação do agente. As técnicas bacteriológicas empregadas apresentam baixa sensibilidade, devido aos métodos drásticos de descontaminação do material, que além destruir os contaminantes, ao mesmo tempo matam alguns bacilos, dificultando o seu isolamento, além da necessidade de uma grande quantidade de bacilos viáveis e um longo tempo de crescimento em meios de cultura apropriados, que pode variar entre 4 a 6 semanas (CORNER, 1994; HAAGSMA, 1995; WARDS et al., 1995; ZANINI et al., 2001).

Para o primo isolamento de $M$. bovis, o meio de cultura mais recomendado é o de Stonebrink isento de glicerina e contendo piruvato de sódio como fonte de carbono. O tempo de crescimento do bacilo varia entre três a cinco semanas de incubação a uma temperatura de $37^{\circ} \mathrm{C}$ (HAAGSMA, 1995).

Runyon, em 1959, propôs uma classificação para as micobactérias segundo características culturais relacionadas a tempo/temperatura de crescimento e de produção de 
pigmentos carotenóides, porém este método necessita de várias semanas para ser concluída (KANTOR, 1979; WARDS et al., 1995).

\subsection{DIAGNÓSTICOS MOLECULARES}

Procedimentos mais avançados para o diagnóstico de tuberculose estão sendo utilizados para a identificação do agente, como as sondas de DNA -ácido dexorribobnucléico, e a técnica de PCR (HAAGSMA, 1995).

Os pesquisadores consideram a técnica de PCR um avanço promissor no diagnóstico rápido da tuberculose, capaz de reduzir o tempo de diagnóstico de meses para poucos dias, e com a vantagem de apresentar uma elevada especificidade e sensibilidade, além da capacidade de detectar quantidades muito pequenas de bacilos na amostra, mesmo que estejam mortos (ABRAHÃO, 1998; KOCAGOZ et al., 1993; BEIGE et al., 1995).

O PCR tem sido amplamente estudado para detectar membros do complexo de $M$. tuberculosis, podendo ser especialmente útil para a detecção direta de M. bovis em amostras de tecidos de bovinos (VITALE et al., 1998; WARDS et al., 1995; ZANINI et al., 2001).

Testes baseados na PCR apresentaram resultados promissores na detecção de M. bovis em amostras clínicas como sangue, tecidos, fluído cérebro-espinhal, muco nasal, leite, e sêmen, mas os resultados destes trabalhos apresentam variações de sensibilidade, devido aos diferentes sistemas de extração de DNA empregados de acordo com as amostras clínicas pesquisadas. E uma das razões para estas diferenças pode ser a presença de resultados falsopositivos ou falso-negativos (AHMED et al., 1999).

Outra técnica molecular que vem sendo aplicada à pesquisa de tuberculose é o spoligotyping, baseada na amplificação enzimática do locus DR (Direct Repeat) do complexo 
M. tuberculosis, ou seja este método detecta a presença ou ausência de espaçadores no locus DR, diferenciando as amostras isoladas, podendo ser empregado na investigação epidemiológica, permitindo a identificação do curso da infecção e das rotas de transmissão da doença, ou mesmo da compreensão da epidemiologia da infecção e que são fundamentais para um melhor controle e erradicação da doença (LIÉBANA et al., 1997; ROMANO et al., 1996; ZANINI et al., 2001). 
O objetivo deste trabalho foi o de através de uma revisão bibliográfica, fornecer um panorama sobre as técnicas moleculares, principalmente a reação da polimerase em cadeia (PCR) ressaltando os avanços e dificuldades encontrados na realização do diagnóstico da tuberculose bovina. 
Inúmeras são as aplicações do teste de PCR, como na medicina forense, no diagnóstico de doenças genéticas, neoplásicas e infecciosas. Na tuberculose, os estudos visam o emprego desta técnica, seja a partir de cultura com o agente já isolado ou através de amostras clínicas (DE WIT et al., 1990; SAKAMOTO et al., 1999).

A técnica de PCR foi introduzida em 1986 por Mullis e Faloona, sendo considerada uma técnica revolucionária, permitindo a amplificação in vitro de um trecho de DNA, inúmeras vezes em poucas horas. Com a capacidade de identificar e amplificar baixos níveis de DNA bacteriano (aproximadamente dois organismos). Uma das vantagens deste método é a capacidade de reproduzir a replicação natural do DNA, com o benefício de ser mais rápido e determinar precisamente o trecho de DNA a ser amplificado, e já no processo natural de replicação, todo o genoma seria amplificado lentamente (ANDRADE, 1993).

A PCR tem a aptidão de separar as fitas de DNA através da desnaturação térmica, através de termocicladores computadorizados, capazes de realizar variações de temperatura precisas e rápidas. A presença de oligonucleotídeos complementares às extremidades do trecho de DNA alvo, ou a ser amplificado, possibilita o pareamento inicial, indispensável para que a polimerase inicie sua replicação. Estes oligonucleotídeos iniciadores recebem o nome de primers (ANDRADE, 1993).

Dentre os elementos que viabilizaram a PCR, um deles foi à descoberta de uma bactéria, Thermus aquaticus, que vive em altas temperaturas. A DNA polimerase extraída dessas bactérias, (Taq polimerase) é habilidade de resistir ao agressivo ciclo térmico da PCR (ANDRADE, 1993). 
Os oligonucleotídeos são considerados elementos chaves da PCR, já que a amplificação do DNA só será possível se houver hibridização do primer com a seqüência de um trecho de DNA da amostra, garantindo a especificidade da reação. Os primers agem como sondas, com a finalidade de selecionar especificamente um trecho determinado do DNA, compreendido entre os dois, para a amplificação. O DNA amplificado será detectado através de um gel de eletroforese corado com um reagente (brometo de etídio),que tem como finalidade separar os fragmentos de DNA, ou por hibridização com sonda genética (ABRAHÃO, 1998; ANDRADE, 1993; COLLINS et al., 1994).

\subsection{O EMPREGO DA PCR PARA DETECTAR TUBERCULOSE ANIMAL}

O método de PCR, assim como outros métodos moleculares apresentam novos progressos para a identificação e detecção de micobactérias, considerado como uma nova oportunidade para um diagnóstico rápido, sensível e especifico. Apesar das vantagens e a clareza dos resultados, todavia, alguns autores afirmam que a sua utilização é restrita no diagnóstico de tuberculose, devido a fatores como complexidade e custo (KLASTER et al., 1998; VITALE et al., 1998; ZANDEN, 2002).

Devido às dificuldades encontradas no diagnóstico de tuberculose em animais, como limitações relacionadas à sensibilidade e especificidade do teste de reação cutânea e o longo período para a confirmação da presença do agente pelos métodos bacteriológicos de rotina, aumentou o interesse pelo desenvolvimento de métodos moleculares para a detecção direta do agente de amostras clínicas, sendo a PCR o teste mais apropriado (RORING et al., 2000; ZANINI et al., 2001). 
O sucesso do método depende da viabilidade do DNA, livre de contaminantes que interferem na amplificação, a escolha correta dos primers para a amplificação do material e emprego de métodos de extração adequados para amostras paulibacilares (KLASTER et al., 1998; RORING et al., 2000; ZANINI et al., 2001).

\subsection{PRIMERS OU OLIGONUCLEOTÍDEOS PARA O MÉTODO DE PCR}

A escolha correta dos primers (elemento do DNA amplificável) é um dos pontos críticos para o sucesso da reação de PCR (SAKAMOTO et al., 1999).

Para detectar M. bovis, o primer selecionado poderá ser: gênero-específico, específico para detectar micobácterias do complexo M. tuberculosis, ou espécie-específico, capaz de detectar apenas M. bovis. Primers específicos para o gênero Mycobacterium spp são capazes de delimitar um segmento de 383 pares de base do gene que codifica o antígeno $65 \mathrm{kDa}-$ hsp65, presentes em todas as micobactérias (TB-1: 5' GAGATCGAGCTGGGAGGATCC 3' e TB-2: 5' AGCTGCAGCCAAAGGTGTT 3'). Sondas específicas para o complexo $M$. tuberculosis capazes de delimitar 419 pares de bases inseridos no gene que expressa o antígeno protéico de 38 kDa-Pab 38 (MT-1: 5' ACCACCGAGCGGTTCGCCTGA 3' e MT-2: 5' GATCTGCGGGTCGTCCCAGGT 3'). Em muitas situações a diferenciação de cepas de M. bovis e M. tuberculosis não é essencial, desta forma seqüências comuns de DNA presentes nestas espécies possibilitam um diagnóstico potencial (COLLINS et al., 1994; SAKAMOTO et al., 1999).

O desenvolvimento de um fragmento genômico espécie-específico para M. bovis foi idealizado em 1995 por Rodriguez e colaboradores, com um produto final de 500 pares de base, mas sem a definição da região do genoma em que o segmento estava inserido 
(JB-21: 5' TCGTCCGCTGATGCAAGTTGC 3' e JB-22: 5' CGTCCGCTGACCTCAAGAAG 3') (RODRIGUEZ et al., 1995; SAKAMOTO et al., 1999). Todavia, este primer é capaz de amplificar pelo menos $25 \%$ de isolados de M. tuberculosis.

Um outro fragmento de DNA empregado em diversos métodos moleculares é um elemento repetitivo denominado IS6110, encontrado várias vezes em diferentes sítios do cromossomo de M. tuberculosis, determinando uma grande heterogeneidade genotípica de isolamentos. O emprego deste primer possibilita distinguir numerosos subtipos do bacilo. Para M. bovis a utilidade deste elemento é menor por ter uma ou poucas cópias.(LATINI et al., 1990). A principal importância do elemento IS6110 é a possibilidade de diferenciar as micobactérias que integram o complexo M. tuberculosis, sendo empregada principalmente em populações onde o status da doença é desconhecido. A diferenciação entre as espécies é feita através do número de cópias de IS6110 que apresentam. No M. tuberculosis, são encontradas entre 8 a 20 cópias. Em cepas de M. bovis encontram-se de 2 a 6 cópias e somente uma única copia do elemento em M. bovis-BCG; como demonstram inúmeros estudos por meio do método de RFLP, onde o IS6110 é amplamente empregado como oligonucleotídeos (ROMANO et al.,1996; VITALE et al., 1998; ZANINI et al., 2000).

As sondas empregadas são desenvolvidas de acordo com as necessidades de cada pesquisa. Wards e colaboradores relatam o emprego de três seqüências alvo de DNA em ensaios de PCR para M. bovis. Um primeiro primer denominado BW1 e BW3, que foi realizado a partir de uma região de 243 pb de um gen responsável pela secreção de uma proteína MPB70, que é específico para M. bovis. Um segundo primer, denominado BW6 e BW7, foi dirigido para uma região de 306 pb da seqüência de inserção de IS8110 com múltiplas cópias, o que aumentava a sensibilidade da reação. E um terceiro primer, BW6 e BW7, destinado à reação de Nested-PCR, dirigido à mesma seqüência de inserção IS8110, que aumentou a sensibilidade de 500 a $1.000 \mathrm{UFC} / \mathrm{mL}$ do primeiro primer para 200 a 500 
UFC/mL (WARDS et al., 1995). Os primers BW6 e BW7 foram também empregados por Ahmed e colaboradores em 1999 (AHMED et al., 1999).

A tentativa de diferenciar M. bovis e M. tuberculosis pelo PCR com o emprego de sondas específicas para uma das cepas tem sido amplamente estudado. Inicialmente, algumas sondas dirigidas à seqüência IS6110 apresentavam resultados promissores. Weil e colaboradores, em 1996, revelaram que nem todas as cepas de M. bovis e M. tuberculosis seguiam um mesmo padrão. Algumas cepas de M. bovis apresentavam alto número de cópias do elemento, assim como cepas de M. tuberculosis apresentavam poucas cópias do mesmo elemento. Outra tentativa foi o emprego de um primer específico para um gen que codifica uma proteína MTP40, presente apenas em M. tuberculosis, mas este gen revelou-se posteriormente que estava presente em muitas, mas não em todas as $M$. tuberculosis e ainda poderia ser encontrado em M. bovis (WEIL et al., 1996; YEBOAH-MANU et al., 2001).

Para diferenciar as micobactérias do complexo M. tuberculosis, as pesquisas atuais descrevem o emprego de PCR multiplex, ou seja, a associação de 2 a 3 oligonucleotídeos específicos na mesma reação. Em 2001, Yeboah-Manu e colaboradores adotaram uma sonda específica para gênero Mycobacterium, associado a uma sonda para complexo M. tuberculosis e outra para espaçadores da região DR 33 e 34. Esta última responsável pela diferenciação entre M. bovis e M. tuberculosis, devido à presença de espaçadores exclusivos em M. bovis. Permitindo, ainda diferenciar M. bovis de M. bovis-BCG, que possui 2 cópias da região 33 e uma da região 34. Apesar de ter apresentado bons resultados, este método não conseguiu diferenciar cepas de M. africanum, por este ser uma estirpe geneticamente intermediária entre M. tuberculosis e M. bovis, desta forma,em locais onde não exista M. africanum, esta PCRmultiplex poderá ser aplicada sem restrição (YEBOAH-MANU et al., 2001). 
A conclusão do genoma do M. bovis, com aproximadamente 4.000 genes, possibilitará o desenvolvimento de primers específicos para a espécie. Além disso, com o sequenciamento das micobactérias, um novo cenário da evolução da doença está sendo proposto, principalmente ao tentar entender e definir o ancestral comum do agente (AAGAARD et al., 2003; BROSCH et al., 2002).

A análise do DNA das micobactérias pertencentes ao complexo M. tuberculosis permitiu inferir que derivam de um ancestral comum. Esta estirpe antiga, ou precursora, diferenciou-se através de deleções irreversíveis em seu DNA, refletidas em diferentes regiões, dando origem a uma linhagem evolutiva: M. canettii, M. tuberculosis, M. africanum, M. microti e M. bovis. Os isolados de M. tuberculosis na atualidade formam clusters diferenciados, como Beijing, Haarlem e African, e evidenciam uma evolução mais recente (BROSCH et al., 2002; SOLA et al., 2003; SREEVATSAN, 1998).

A hipótese aceita durante anos de que a tuberculose humana era uma adaptação da tuberculose animal ao homem perdeu seus fundamentos, os resultados de estudos do genoma de $M$. bovis demonstram que este sofreu inúmeras deleções quando comparado ao genoma de M. tuberculosis, sendo o genoma de do bacilo bovino menor que o de M. tuberculosis. (BROSCH et al., 2002).

\subsection{EXTRAÇÃO DO DNA MICOBACTERIANO}

Um fator de relevante importância é o desenvolvimento de um método apropriado para extração de um pequeno número de organismos de lesões teciduais e a exposição do DNA presente nestes organismos para a amplificação por PCR.(COLLINS et al., 1994). 
Técnicas utilizadas com sucesso na extração de DNA de M. tuberculosis de amostras clínicas de escarro mostram-se inadequadas para o processamento de amostras de M. bovis em tecido bovino. Isto decorre do fato de que a quantidade de bacilos de M. tuberculosis pode ser maior que de bacilos de $M$. bovis e conseqüentemente a extração do DNA de $M$. tuberculosis nestas amostras é de maior facilidade. Entretanto a melhora na extração dos ácidos nucléicos possibilitaria aumentar a sensibilidade do método para amostras de tecido bovino (COLLINS et al., 1994; TAYLOR et al., 2001).

Os primeiros estudos para detecção direta de M. bovis de tecidos bovinos através da PCR foram realizados em 1995, e os valores práticos citados incluíam a rapidez da detecção e a habilidade de detectar bacilos inviáveis, mas conclui-se que a PCR apresentava limitações, principalmente para detectar M. bovis em amostras paucibacilares, e que não poderia substituir a cultura, com sensibilidade muito superior na detecção direta, enquanto métodos apropriados de extração de DNA para tecidos bovinos não fossem desenvolvidos (COLLINS et al., 1994; RORING et al., 2000).

O método de PCR é muito sensível para diagnóstico de culturas de micobactérias, mas não apresenta o mesmo resultado para amostras clínicas, principalmente em tecidos, isto devido à pequena quantidade de bacilos. Para que a técnica tenha uma performance melhor que a cultura, a sensibilidade do método de extração é essencial. A diversidade de metodologias e de materiais empregados dificultam a comparação da sensibilidade entre eles (RORING et al., 2000).

Uma das questões essenciais é a falta de um procedimento eficiente para concentrar as micobactérias no pellet para a identificação, principalmente devido à flutuação e a tensão superficial encontrada nas mesmas (ANTOGNOLI et al., 2001). 
Inúmeros são os protocolos empregados na extração de DNA de amostras clínicas, muitos deles utilizam kits comerciais, outros empregam métodos mais simples como a extração por solventes orgânicos (fenol-clorofórmio), mas todos apresentam diferentes resultados, sem que haja um consenso em qual o melhor método a ser empregado (RORING et al., 2000).

Apesar de ser um método diagnóstico promissor, o seu uso, especialmente em locais com altos índices da doença é limitado devido ao custo e a complexibilidade do método. Um dos fatores limitantes, além dos citados é a necessidade de estandardizar o método, bem como o controle na qualidade do congelamento e refrigeração dos ingredientes utilizados na preparação do mix para a reação de PCR (KLASTER et al., 1998).

\subsection{MÉTODOS DE EXTRAÇÃO DE DNA DE M. BOVIS}

Os trabalhos que utilizam a PCR para detecção direta de M. bovis em tecidos são poucos entre eles: Wards e colaboradores, 1994; Aranaz e colaboradores, 1995; e Vitale e colaboradores, 1998, mas com grande variedade de metodologias para a extração de DNA, que normalmente são trabalhosas e consomem muito tempo (ANTOGNOLI et al., 2001; RORING et al., 2000).

Wards e colaboradores em 1995 analisaram diferentes tipos de protocolos de extração de DNA de M. bovis. Alguns protocolos utilizavam pérolas magnéticas e pérolas de Zircônio, o terceiro método utilizava uma substância denominada de Chelex ${ }^{\circledR}$ a $10 \%$ (Biospec Products) e o último utilizava um copo para triturar (Geneclean) de acordo com instruções do fabricante. Contudo, os melhores resultados foram obtidos após a digestão do material com proteinase $\mathrm{K}$ a $10 \%$. Estudos demonstraram que o uso de resinas como o Chelex ${ }^{\circledR} \mathrm{e}$ proteinase K são simples e efetivos (ANTOGNOLI et al., 2001). 
Kits comercias de extração como: QIAamp DNA Blood Mini Kit - Qiagen® e Wizard Plus Minipreps DNA Purification System - Promega ${ }^{\circledR}$, entre outros foram avaliados apresentando sensibilidade similar ao diagnóstico por coloração de Ziehl-Neelsen. A grande maioria destes são testados com isolamentos de culturas e apresentam algumas desvantagens, como a especificidade para algumas micobactérias. Resultados negativos podem ser decorrentes de biomassa inadequada, principalmente em meios de cultura líquidos, ou pela inibição do teste pela amostra. Além disso, a detecção de micobactérias em amostras clínicas é limitada e muitos métodos não diferenciam os membros do complexo M. tuberculosis. Testes como o MTD® da Gen Probe descrevem-se como rápido, fácil e capaz de identificar poucos bacilos em tecidos, mas a sensibilidade do teste foi comparada com a sensibilização da pele e não com a cultura da micobactéria (RORING et al., 2000; YEBOAH-MANU et al., 2001). Um dos grandes empecilhos para o emprego dos testes comerciais, além dos enumerados anteriormente, refere-se ao custo alto que se torna proibitivo para um diagnóstico de rotina (RORING et al., 2000).

Uma das alternativas para garantir melhores resultados do PCR é o emprego de seqüências de captura de DNA, que apresentam bons resultados em amostras paucibacilares, e desta forma apresentam maior sensibilidade que a cultura e métodos que empregam solventes na extração (RORING et al., 2000; TAYLOR et al., 2001).

Para verificar a viabilidade e determinar um método prático e eficiente de extração, amostras de leite inoculadas com diferentes diluições do agente, foram avaliadas com diversos protocolos comerciais e por métodos de extração com fenol-clorofórmio-álcool isoamílico modificados. Os resultados encontrados permitiram concluir que para o leite, protocolos à base de fenol-clorofórmio são viáveis para o diagnóstico de rotina devido à facilidade, custo accessível e o tempo necessário para sua realização (ROXO et al., 2002). 
Estudos comparando resultados de amostras especialmente estandardizadas processadas em diversos laboratórios e com diferentes métodos de extração de DNA apresentaram grandes variações na sensibilidade e especificidade (DEL PORTILLO et al., 1996).

\subsection{SENSIBILIDADE DA PCR}

Uma das grandes vantagens mencionadas sobre a PCR é sua alta sensibilidade e especificidade, além de ser um diagnóstico rápido quando comparado a outros métodos diagnósticos (LIÉBANA et al., 1995; RORING et al., 2000; WARDS et al., 1995).

A sensibilidade do teste de PCR é influenciada pelo método de extração de DNA, parâmetros cíclicos e os procedimentos empregados para detectar e identificar o produto da técnica. Para aumentar a sensibilidade, o DNA amplificado poderia ser submetido a uma segunda PCR, com primers diferentes, denominada de Nested-PCR (ZANDEN, 2002).

A sensibilidade da PCR esta extremamente relacionada ao tipo de material a partir do qual será extraído o DNA. Amostras como o leite, usualmente apresentam sensibilidade baixa na PCR. A dificuldade de detecção do agente pode ser influenciada pelas soluções empregadas no método, a lise da parede celular e o pequeno número de bacilos presentes, apresentando variações de acordo com o método empregado para isolar o ácido nucléico (CORNEJO et al., 1998)

O método de PCR não é capaz de diferenciar entre organismos colonizadores e infectantes, viáveis ou não. A alta sensibilidade do método pode propiciar resultados falso-positivos, principalmente devido à capacidade de detectar micobactérias não viáveis, 
através de contaminação das amostras com produtos de PCR (MAC FADDEN et al., 1990; ZANDEN, 2002).

Para avaliar a sensibilidade do teste, alguns autores empregam diluições seriadas, normalmente decrescentes, de DNA do agente com o objetivo de estabelecer o limite de sensibilidade do método de extração e do primer empregado. A quantidade de material detectado pode ser expressa em fentogramas, que inclui todo o DNA, do agente, do tecido e até do próprio animal, ou por organismos totais contáveis, estabelecendo a diferença entre os organismos viáveis e os contáveis. Em relação aos outros métodos de diagnóstico, a PCR deve ser comparada ao diagnóstico padrão equivalente, que é a cultura e não com métodos como a coloração ou testes de sensibilização, que medem diferentes fatores da doença (RODRIGUEZ et al., 1995; RORING et al., 2000; VITALE et al., 1998; WARDS et al., 1995).

O emprego de programas de controle de qualidade para diagnósticos moleculares aumentou a sensibilidade e a especificidade do método de PCR em contraste com o que ocorria há 10 anos atrás, principalmente para M. tuberculosis (ZANDEN, 2002).

\subsection{ESPECIFICIDADE DA PCR}

A especificidade dos testes moleculares depende da seleção dos primers, condições adequadas para amplificação e provas de hibridização contra o produto da PCR. Muitos elementos de inserção de micobactérias são utilizados por serem limitados para uma espécie individual. Entretanto, seqüências de inserção que apresentam mobilidade podem causar transtornos, já que não devem carrear genes que são necessários para o crescimento daquele organismo (ZANDEN, 2002). 
Falso-negativos podem ocorrer especialmente em amostras clínicas contendo inibidores da amplificação. Com a finalidade de minimizar estes erros, uma prática comum é a adição de controles positivos a partir de pequenas quantidades de DNA do agente em questão, DNA sintético ou clones do DNA (MAC FADDEN et al., 1990; ZANDEN, 2002).

Algumas seqüências, como IS6110, que inicialmente eram exclusivas e presentes em todas as micobactérias do complexo M. tuberculosis, evidenciou-se em 2002, isolamentos de M. tuberculosis sem a presença de IS6110, podendo ocasionar diagnósticos falhos (ZANDEN, 2002).

Para que a especificidade dos oligonucleotídeos seja garantida estudos prévios devem ser realizados, aplicando vários gêneros de bactérias, como Nocardia spp, Streptococus spp e Sthaphylococus spp (TAYLOR et al., 2001).

O sequenciamento completo do genoma de M. bovis poderá num futuro próximo permitir o desenvolvimento de primers adequados de acordo com o método molecular a ser empregado (BROSCH et al., 2003; TAYLOR et al., 2001).

\subsection{PROBLEMAS DE CONTAMINAÇÃO}

A contaminação é um dos maiores dificuldades dos laboratórios de biologia molecular, principalmente em tuberculose. Um dos principais problemas é a contaminação cruzada entre espécies, normalmente através de amplificações de culturas de M. bovis e M. tuberculosis, e também pela transferência de algumas moléculas da seqüência alvo para reações de amplificação a serem realizadas, resultando muitas vezes em falso-positivo (KANDUMA et al., 2003; ZANDEN, 2002). 
Relatos de contaminação cruzada variam entre 0,1 a $65 \%$. Em laboratórios bem regulados e fiscalizados as taxas de contaminação são menores que 1\% (KANDUMA et al., 2003).

Com o intuito de minimizar os entraves da contaminação, alguns procedimentos são aplicados como a inativação fotoquímica, desintegração do ácido nucléico com ácido clorídrico, e essencialmente a divisão do laboratório de biologia molecular em salas de processamento, análise do DNA, e do produto da PCR denominadas de áreas sujas e limpas. Precauções com o DNA e com o produto da PCR deverão ser adotadas. O mix da reação de PCR e o DNA extraído deverão ser armazenados congelados a aproximadamente $-20^{\circ} \mathrm{C}$, e durante os processamentos do DNA, processar sob refrigeração, monitorando a performance da PCR e usando controles dos procedimentos de extração e isolamento do DNA de amostras clínicas (ZANDEN, 2002).

\section{OUTROS MÉTODOS MOLECULARES}

\subsection{SEPARAÇÃO DE MOLÉCULAS POR ELETROFORESE}

A eletroforese consiste na separação através de corrente elétrica das moléculas de acordo com a sua carga elétrica e peso molecular. O aperfeiçoamento deste procedimento permitiu a separação de proteínas em gel de poliacrilamida/uréia e de ácidos nucléicos em gel de agarose (ANDRADE, 1993). 


\subsection{TRANSFERÊNCIA PARA A FASE SÓLIDA}

Um dos problemas do método de eletroforese para obter informações adicionais era devido à dificuldade de trabalhar com suportes semi-sólidos, como géis. A inovação ocorreu quando em 1976, Southern possibilitou a transferência quantitativamente do material separado para um suporte sólido, como filtro de nitrocelulose ou membrana de náilon, denominada de Southern blot. A essa técnica seguiu-se posteriormente a transferência de RNA, denominada então de Northern blot e das proteínas, de Western blot (ANDRADE, 1993).

\subsection{RFLP (RESTRICTION FRAGMENT LENGTH POLYMORPHISM)}

A denominação RFLP deriva do vocabulário inglês restriction fragment length polymorphism e refere-se ao polimorfismo do tamanho dos fragmentos gerados por enzimas bacterianas que têm a capacidade de clivar moléculas de DNA estranho que possam penetrar na célula, constituindo uma defesa primitiva de organismos não nucleados (ANDRADE, 1993; COLLINS et al., 1994).

O emprego deste mecanismo em dupla hélice de DNA ocorre em pontos conhecidos denominados de sítios de restrição, produzindo seqüências de 4 a 8 nucleotídeos, exclusivas para cada enzima. Desta forma, o uso do RFLP produz um padrão de fragmentos, que caracteriza excepcionalmente a cepa da qual o DNA foi isolado (ANDRADE, 1993).

As etapas da técnica de $R F L P$ consistem em digestão do DNA genômico por uma enzima de restrição, eletroforese em gel de agarose, desnaturação do DNA no gel, transferência do DNA do gel para uma membrana semi-sólida de nylon, fixação do DNA à membrana, posteriormente marcação com sonda genética, hibridização da sonda com o DNA 
e, por último, a lavagem, revelação e documentação da amostra. A diferenciação de cepas do complexo M. tuberculosis através deste método baseia-se nas freqüências de certas seqüências de DNA cromossômico. Em tuberculose, tanto bovina quanto humana, inúmeros são os estudos na tentativa de estandardizar um método para explorar o polimorfismo dessas cepas (KANDUMA et al., 2003; SAKAMOTO, 2001; ZANDEN, 2000).

Para identificação das estirpes, o método de $R F L P$ é fundamentado no número variável de elementos de inserção, principalmente a seqüência de IS6110, presentes no genoma das diferentes estirpes e do alto grau de variação dos sítios genômicos de integração do complexo M. tuberculosis. No final do século passado, mais de 30 elementos de inserção IS foram identificados em micobactérias. Mas, pesquisas do inicio do século XIX, confirmam a aptidão da $R F L P$ com marcador IS 6110 , sendo proposto como a prova padrão para tipificação de M.tuberculosis (KANDUMA et al., 2003; ROMANO et al., 1996; SAKAMOTO, 2001; ZANDEN, 2000).

Um dos maiores problemas do emprego da RFLP para tipificar cepas de M. bovis é a quantidade de massa celular necessária para digerir no mínimo $1 \mu \mathrm{g}$ de DNA purificado e íntegro, que além de demandar tempo devido à necessidade de subcultivo, dificilmente se obtém a massa celular necessária (SAKAMOTO, 2001).

Uma das maiores vantagens do emprego da técnica é a possibilidade de desenvolver estudos epidemiológicos de surtos de tuberculose humana ou animal. Com o advento da AIDS, estudos epidemiológicos são cruciais no cenário social, devido ao número de pacientes imunocomprometidos que podem entrar em contato com um alto número de hospedeiros susceptíveis em potencial. Além de determinar a evolução e o modo de transmissão da doença em determinada região, colaborando para que estratégias eficazes de combate à doença sejam estabelecidas (ABRAHÃO, 1998; BLÁSQUEZ et al., 1997; ROMANO et al., 1996). 


\subsection{PFGE (PULSED FIELD GEL ELECTROPHORESIS)}

O método de $P F G E$ foi descrito em 1984, por Schwartz e Cantor como um novo caminho para separar o DNA, e simplificar o método de RLFP. Utilizado com menor freqüência, emprega enzimas que digerem fragmentos com maior peso molecular, aumentando o limite de separação do DNA em gel de agarose de 30 a $50 \mathrm{~Kb}$ para $10.000 \mathrm{~Kb}$. Após a primeira descrição, uma sucessão de trabalhos descreveram melhorias na técnica e nos métodos, resultando na avaliação constante de procedimentos de rotina e testes comerciais (JOPPA, 2004; KANDUMA et al., 2003).

As aplicações deste método são inúmeras e diversificadas entre elas: clonagem de DNA, através de cromossomos artificiais de leveduras, clonagem de vetores, detecção de cromossomos degradados ou rompidos, determinação do número e tamanhodos cromossomos de leveduras, fungos e parasitas, além da importância de descobertas epidemiológicas e a biologia da população de muitos patógenos. Entretanto, estudos sobre o emprego do $P F G E$ para a epidemiologia molecular de M. tuberculosis são escassos (JOPPA, 2004; SINGH et al, 1999).

Uma das limitações desta técnica consiste em que o pequeno polimorfismo característico para diferenciar cepas pode não produzir discriminação suficiente (KANDUMA et al., 2003). 


\subsection{SPOLIGOTYPING}

O spoligotyping possibilita a detecção e tipificação das micobactérias do complexo M. tuberculosis, sendo indicado como técnica de eleição para a comparação de estirpes com poucas cópias de IS6110, além de permitir a diferenciação de estirpes de M. bovis e M. tuberculosis (SAKAMOTO, 2001).

A técnica de spoligotyping foi descrita por Kamerbeek e colaboradores em 1997, como uma técnica rápida e introduzido-a como um método para determinar a epidemiologia molecular da tuberculose humana. Baseado na amplificação por PCR do DNA presente em um locus cromossomal particular, denominado de região de repetição direta - DR, presente apenas nas micobactérias do complexo M. tuberculosis e com alto polimorfismo entre seus espaçadores (ARANAZ et al., 1996; SAKAMOTO, 2001; ZUMARRAGA, 1999).

O elemento DR foi identificado por Hermans e colaboradores em 1991, quando caracterizaram a inserção do elemento IS986 de M.bovis-BCG e o DNA cromossomal paralelo a este elemento. A região DR neste agente apresenta seqüências repetidas de 36 pb e o número de cópias de DR foi determinado como 49, mas o número de elementos DR em outras cepas do complexo apresenta grande variação Foi determinado também, que cada DR apresentava em anexo um espaçador não-repetitivo denominado DVR (Direct Variant Repeat). Ao comparar as regiões DR de vários isolamentos, observou-se que a ordem dos espaçadores era aproximadamente a mesma em todos os isolamentos, as diferenças encontravam-se na ocorrência de deleções e inserções dos espaçadores DVR's. O polimorfismo de vários isolamentos é comprovado pela ausência ou presença de um ou mais DVR's (ARANAZ et al., 1996, SAKAMOTO , 2001). 
A tipificação dos oligonucleotídeos espaçadores, ou seja, spoligotyping, consiste na detecção da presença ou ausência dos espaçadores de uma seqüência conhecida, realizado em dois passos. Inicialmente realiza-se uma PCR para amplificar os espaçadores presentes entre as DR's; os oligonucleotídeos usados são baseados na seqüência da DR e permite a amplificação dos espaçadores entre as DR's. Posteriormente, ocorre a hibridização com um conjunto de oligonucleotídeos imobilizados em uma membrana, sendo que cada um deles constitui-se em uma seqüência específica de espaçador (ARANAZ et al., 1996; COUSINS et al., 1998; SAKAMOTO, 2001; ZUMARRAGA, 1999).

Uma das vantagens relatadas inicialmente seria a rapidez, o custo baixo e a tipificação das estirpes de M. bovis, assim como de M. tuberculosis, possibilitando estudos epidemiológicos em regiões endêmicas e a adequação de estratégias de prevenção e controle. Entretanto, alguns estudos demonstram que apenas o spoligotyping não seria suficiente para correlações epidemiológicas entre as cepas de M. bovis, havendo a necessidade de associações com outros métodos moleculares como a análise de RFLP com DR PGRS, já que a técnica de spoligotyping possui menor discriminação que as técnicas citadas acima (ARANAZ et al., 1996; COUSINS et al.,1998; SAKAMOTO, 2001; ZUMARRAGA et al., 1999).

A técnica de spoligotyping é conveniente para exames iniciais de triagem pela facilidade de interpretação dos resultados e a rápida detecção e direta tipificação de isolamentos de M. bovis de amostras clínicas. No futuro, a melhora no grau de diferenciação de amostras de M. bovis poderão ser obtidas através do emprego de novas seqüências de espaçadores derivados da analise das seqüências de isolamentos do bacilo bovino, que poderão levar à confecção de membranas específicas para M. bovis (ZUMARRAGA et al., 1999). 


\subsection{PRA (PCR COM ANÁLISE DE RESTRIÇÃO)}

O gênero Mycobacterium compreende cerca de 70 espécies, patogênicas ou não para seres humanos e animais. Devido à importância clínica, a dificuldade e o tempo necessários para diferenciá-las pelas características morfológicas e bioquímicas, pesquisadores investem em métodos moleculares de diagnósticos, sendo o principal objetivo a rápida detecção e identificação destas micobactérias. Um dos métodos moleculares preferidos é a PCR com análise de restrição, ou PRA, devido à simplicidade, ao custo efetivo e por não envolver radioisótopos (BUM-JOOM et al., 2001; PALOMINO, 2002).

O método de PRA consiste na habilidade de enzimas de restrição denominadas endonucleases de cortar o DNA em determinados fragmentos com determinada seqüência de bases. O produto destes cortes no DNA produz fragmentos de diferentes tamanhos, que serão separados de acordo com o seu peso molecular, por eletroforese em ágar gel de alta resolução (ABRAHÃO, 1998).

Telenti e colaboradores em 1993, baseados na variação da seqüência de nucleotídeos do locus hsp65 em diferentes espécies de micobactérias, sugeriram um método de identificação através da análise do polimorfismo determinado pelos fragmentos de digestão do gene em questão, envolvendo a amplificação de um fragmento de 441 pares de base, posteriormente digeridos pelas enzimas BstEII e HaeII, possibilitando por meio de chaves de classificação a diferenciação de 29 espécies e subespécies de micobactérias, incluindo entre elas M. avium e M. intracellulare. Em 1997, novos algoritmos foram propostos por Taylor e colaboratodes e Devalois e colaboradores, com 34 espécies e subespécies. Estudos recentes no Brasil, que aplicaram esta técnica a 18 estirpes do Complexo M. avium, incluindo cepas de referência, isolamento de humanos e animais, confirmaram o sucesso desta técnica na 
diferenciação de Mavium, M. intracellulare e M. scrofulaceum (DEVALOIS et al., 1997; LEÃO et al., 1999; ROCHA et al., 2002; TELENTI et al., 1993; TAYLOR et al., 1997).

Com o avanço da técnica do PRA se almeja conseguir identificar através das enzimas de restrição e das chaves de classificação as cerca de 70 espécies de micobactérias conhecidas, assim como no método de clássico de identificação morfológica e bioquímica, mas de forma mais rápida, barata e segura, ou ao menos lograr um método de triagem na identificação das micobactérias. 
Com o avanço da biologia molecular, e das técnicas empregadas, pesquisas sobre a aplicação da PCR no diagnóstico da tuberculose estão sendo publicadas. Esta técnica apresenta importância no diagnóstico, devido à capacidade de diferenciar as espécies muito mais rapidamente comparando-se aos métodos clássicos. Contudo, não são muitos os estudos aplicados à pesquisa direta de bacilos em amostras clínicas, principalmente de M. bovis, e necessitam de mais avaliações, com a finalidade de evitar resultados falso-positivos ou falsonegativos, e validar a sua performance sob as condições dos países nos quais serão usados, principalmente nos países tropicais (WORLD HEALTH ORGANIZATION, 1994; WARDS et al., 1995).

As principais barreiras para a aplicação do método de PCR na rotina laboratorial são a extração de DNA e a escolha de primers adequados. Estudos relacionados com os métodos de extração existem, mas empregam soluções ou kits comerciais inadequados à realidade do produtor brasileiro. A maior dificuldade no processo de extração está relacionada principalmente à pequena quantidade de bacilos presentes em lesões de bovinos tuberculosos, a dificuldade em concentrar o DNA no pellet e a presença de DNA do animal, além do DNA do agente.

A escolha dos primers também é fundamental para que a sensibilidade e especificidade do teste sejam alcançadas. Até hoje, não existem primers específicos para M. bovis. Primers desenvolvidos por Rodriguez e colaboradores, JB21 e JB22, tidos como específicos para o bacilo bovino, identificam também algumas amostras de M. tuberculosis. O sequenciamento genético do M. bovis poderá no futuro garantir a identificação de regiões específicas e exclusivas do agente permitindo desenhar sondas específicas. A finalidade de 
obter um método de extração e primers eficazes e eficientes, de acordo com a realidade destes países é primordial para que técnicas moleculares possam ser empregadas com sucesso na rotina de diagnóstico.

O teste tuberculínico e o abate dos animais reagentes são consideradas as melhores armas para o combate da tuberculose nos animais. A inspeção veterinária, mesmo que possua falha, já que o diagnóstico definitivo depende da identificação do agente causal, tem como finalidade avaliar o estado das carcaças, impedindo o consumo humano de produtos que representem risco à saúde (BALIAN, 1997). Ao desenvolverem-se métodos diagnósticos para a eliminação dos animais afetados, evita-se a contaminação de novos rebanhos, o que acarreta perdas econômicas relacionadas ao ganho de peso, produção leiteira e condenação de carcaças, restrição comercial, além de evitar também a transmissão da doença para outras espécies de importância econômica, bem como para o homem.

A aplicação de metodologias moleculares que tem como objetivo auxiliar no diagnóstico laboratorial de lesões suspeitas de tuberculose, alia aos dados obtidos pelo isolamento do agente em laboratório (método clássico), permitindo uma expressiva redução no tempo necessário para o diagnóstico da tuberculose, o que possibilitaria a diferenciação das lesões sugestivas de tuberculose em carcaças seqüestradas em frigorífico. Ainda, os novos métodos de epidemiologia molecular poderão constituir-se em armas importantes na adoção de estratégias de controle e erradicação da doença. 


\section{REFERÊNCIAS ${ }^{1}$}

AAGAARD, C.; GOVAERTS, M.; OKKELS, L.M.; ANDERSEN, P.; POLLOCK, J.M. Genomic Approach to Identification of Mycobacterium bovis diagnostic antigens in Cattle. Journal of Clinical Microbiology, v. 41, n. 8, p. 3719-3728, 2003

ABDALA, A.; TARABLA, H.; BERTERO, S.; TORRES, P. Vigilancia epidemiológica de la tuberculosis bovina en el Departamento de Castellanos, Santa Fe. Disponível em: $<$ http://www.rafaela.inta.gov.ar/anuario1999/p37.htm $>$. Acesso em: 10 jan. 2003.

ABRAHÃO, R.M.C.M. Tuberculose humana causada pelo Mycobacterium bovis: considerações gerais e a importância dos reservatórios animais 1998. 273 f. Dissertação (Mestrado) - Faculdade de Saúde Pública da Universidade de São Paulo, São Paulo, 1998.

AHMED, A. S. N.; KHAN, J. R.; GANAI, N. A. DNA amplification assay for rapid detection of bovine tubercle bacilli in semen. Animal Reproduction Science, v. 57, p. 15-21, 1999.

ANDRADE, L.E.C. Princípios de biologia molecular e suas aplicações em medicina. Revista da Associação Médica Brasileira, v. 39, p. 175-186, 1993.

ANTOGNOLI, M. C.; SALMAN, M. D.; TRIANTIS, J.; HERNÁNDEZ, J.; KEEFE, T. A one-tube nested polymerase chain reaction for the detection of Mycobacterium bovis in spiked milk samples: an evaluation of concentration and lytic techniques. Journal Veterinary Diagnostic Investigation, v. 13, p. 111-116, 2001.

ARANAZ, A.; LIÉBANA, E.; MATEOS, A.; DOMINGUEZ, L.; VIDAL, D.; DOMINGO, M.; GONALEZ, O.; RODRIGUEZ-FERRI, E. F.; BUNSCHOTEN, A.; VAN EBDEN, J. D. A.; COUSINS, D. Spacer oligonucleotide typing of Mycobacterium bovis strains from cattle and other animals: a tool for studying epidemiology of tuberculosis. Journal of Clinical Microbiology, v. 34, n. 11, p. 2734-2740, 1996.

BALIAN, S. C.; RIBEIRO, P.; VASCONCELLOS, S. A.; PINHEIRO, S. R.; FERREIRA NETO, J. S.; GUERRA, J. L.; XAVIER, J. G.; MORAIS, Z. M.; TELLES, M. A. S. Linfadenites tuberculóides em suínos abatidos no estado de São Paulo, Brasil: aspectos macroscópicos, histopatológicos e pesquisa de micobactérias. Revista de Saúde Pública, v. 31, n. 4, p. 391-397, 1997.

BEER, J. Enfermedades infecciosas de los animales domesticos. Zaragoza: Editorial Acribia, 1981. v. 2.

\footnotetext{
${ }^{1}$ Conforme as Diretrizes para apresentação de dissertação e tese na Faculdade de Medicina Veterinária e Zootecnia da Universidade de São Paulo. 4. ed. ver. atual. ampl. São Paulo: FMVZ-USP, 2003. 84 p.
} 
BEIGE, J.; LOKIES, J.; SCHABERG, T.; FINCKH, U.; FISCHER, M.; MAUCH, H.; LODE, H.; KÖHLER, B.; ROLFS, A. Clinical evaluation of a Mycobacterium tuberculosis PCR assay. Journal of Clinical Microbiology, v. 33, n. 1, p.90-95, 1995.

BIER, O. Micobactérias. In:____Bacteriologia e imunologia. 19. ed. São Paulo: Melhoramentos, 1978. p. 585-610.

BLÁZQUEZ, J.; MONTEROS, L. E. E.; SAMPER, S.; MARTÍN, C.; GUERRERO, A.; COBO, J.; EMBDEN, J. V; BAQUERO, S.; GÓMEZ-MAMPASO, E. Genetic characterization of multi drug-resistance Mycobacterium bovis strains from a hospital outbreak involving human immunodeficiency virus-positive patients. Journal Clinical of Microbiology, v. 35, n. 6, p. 1390-1393, 1997.

BOOM, R.; SOL, C. J. A.; SALIMANS, M. M. M.; JANSEN, C. L.; WERTHEIM-Van DILLEN, P. M. E.; VAN DEER NOORDAA, J. Rapid and simple method for purification of nucleic acids. Journal of Clinical Microbiology, v. 28, n. 3, p. 495-503, 1990.

BRASIL. Ministério da agricultura, pecuária e do abastecimento, Programa Nacional de Controle e Erradicação da Brucelose e Tuberculose, 2001. Disponível em: $<\mathrm{http} /$ /www.cbra.org.br/Programa.doc. $>$. Acesso em: 16 jan. 2004.

BROSCH, R.; GORDON, S.V; MARMIESSE, M.; BRODIN, P.; BUCHRIESER, C.; EIGLMEIER ,K.; GARNIER, T.; GUTIERREZ, C.; HEWINSON, G.; KREMER, K.; PARSONS, L. M.; PYM, A. S.; SAMPER, S.; VAN SOLLIGEN, D.; COLE, A. A new evolutionary scenario for the Mycobacterium tuberculosis complex. Proccedings of National Academy of Sciences of the United States of America, v. 99, n. 6, p. 3684-3689, 2002.

BUM-JOO, K; KEUN-HWA, L.; BO-NA, P.; SEO-JEONG, K.; GILL-HAM, B.; SANGJAE, K.; YOON-HOH, K. Differentiation of mycobacterial species by PCR- restriction analysis of DNA (342 base pairs) of the RNA polymerase gene (rpoB). Journal of Clinical Microbiology, v. 39, n. 6, p. 2102-2109, 2001.

COLLINS, D. M.; RADFORD, A. J.; DE LISLE, G.W.; BILLMAN-JACOBE, H. Diagnosis and epidemiology of bovine tuberculosis using molecular biological approaches. Veterinary Microbiology, v. 40, p. 83-94, 1994.

CORNEJO, B. J; SAHAGUN-RUIZ, A.; SUAREZ-GUEMES, F.; THORTON, C.G; FICHT, T. A.; ADAMS, L.G. Comparison of C18- Carboxypropylbetaine and glass bead DNA extraction methods for detection of Mycobacterium bovis in bovine milk samples and analysis of samples by PCR. Applied and Environmental Microbiology, v. 64, n. 8, p. 3099-3101, 1998.

CORNER, L.A. Post mortem diagnosis of Mycobacterium bovis infection in cattle.

Veterinary Microbiology, v. 40, p. 53-63, 1994. 
CORRÊA, W.M.; CORRÊA, C.N.M. Enfermidades infecciosas dos mamíferos domésticos. São Paulo: Varela, 1992. 843 p.

COSIVI, O.; GRANGE, J. M.; DARBON, C. J.; RAVIGLIONE, M. C.; FUJIKURA, T.; COUSINS, D.; ROBINSON, R. A.; HUCHZERMEYER, H. F.A. K.; KANTOR, I.; MESLIN, F. X. Zoonotic tuberculosis due to Mycobacterium bovis in developing countries. Emerging Infections Diseases, v. 4, p. 59-57, 1998.

COUSINS, D.V.; BASTIDA R, CATALDI A, QUSE V, REDROBE S, DOW S, DUIGNAN P, MURRAY A, DUPONT C, AHMED N, COLLINS DM, BUTLER WR, DAWSON D, RODRIGUEZ D, LOUREIRO J, ROMANO MI, ALITO A, ZUMARRAGA M, BERNARDELLI A. Tuberculosis in seals caused by a novel member of the Mycobacterium tuberculosis complex: Mycobacterium pinnipedii sp. nov. International Journal of Systematic and Evolutionary Microbiology, v. 53, p. 1305-1314, 2003.

COUSINS, D. V.; WILLIANS, S.; LIÉBANA, E.; ARANAZ, A.; BUNSCHOTEN, A; EMBDEN J. V.; ELLIS, T. Evaluation of four DNA typing techniques in epidemiological investigations of bovine tuberculosis. Journal of Clinical Microbiology, v. 36, n. 1, p. 168178, 1998.

COUSINS, D. V.; WILTON, S. D.; FRANCIS, B. R. Use of DNA amplification for the rapid identification of Mycobacterium bovis. Veterinary Microbiology, v. 27, n. 2, p. 187-195, 1991.

COSIVI, O.; GRANGE, J. M.; DARBON, C. J.; RAVIGLIONE, M C.; FUJIKURA, T.; COUSINS, D.; ROBINSON, R. A.; HUCHZERMEYER, H.F.A.K.; KANTOR, I; MESLIN, F.X. Zoonotic tuberculosis due to Mycobacterium bovis in developing countries. Emerging Infections Diseases, v. 4, p. 59-57, 1998

DE WIT, D; STEYN, L.; SHOEMAKER, S.; SOGIN, M. Direct detection of Mycobacterium tuberculosis in clinical specimens by DNA amplification. Journal of Clinical Microbiology, v. 28, n. 11, p. 2437-2441, 1990.

DEVALOIS, A.; GOH, K. S.; RASTOGI, N. Rapid identification of mycobacteria to species level by PCR-restriction fragment length polymorphism analysis of the $h s p 65$ gene and proposition of an algorithm to differentiate 34 mycobacterial species. Journal of Clinical Microbiology, v. 35, n. 11, p. 2969-2973, 1997.

DEL PORTILLO, P.; THOMAS, M. C.; MARTINEZ, E; MARAÑÓN, C.; VALLADARES, B.; PATARROYO, M. E.; LÓPEZ, M. C. Multiprimer PCR system for differential identification of mycobacteria in clinical samples. Journal of Clinical Microbiology, v. 34, n. 2, p. 324-328, 1996. 
ESSEY, M. A.; KOLLER, M. A. Status of bovine tuberculosis in North America. Veterinary Microbiology, n. 40, p. 15-22, 1994.

FERREIRA NETO, J.S.; BERNARDI, F. O controle da tuberculose bovina. Disponível em: $<$ http://www.bichoonline.com.br/artigos/ha0008.htm>. Acesso em: $18 \mathrm{dez} .2001$.

.JOPPA, B. Pulsed field eletrophoresis for separation of large dna. Disponível em: $<$ http://www.nal.usda.gov/pgdic/Probe/v2n3/puls.html $>$. Acesso em 24 jan. 2004.

GERVOIS, M.; VAILLANT, J. M.; FONTAINE, J. F.; LAROCHE, G.; DUBOIS, G. Epidemiologie de l'infection humaine par Mycobacterium bovis. Archivio Monaldi per la Tisiologia e le Malattie dell'Apparato Respiratorio, v. 27, p. 294-317, 1972.

GRANGE, J. M.; YATES, M. D. Zoonotic aspects of Mycobacterium bovis infection in cattle. Veterinary Microbiology, v. 40, n. 1-2, p. 137-152, 1994.

HAAGSMA, J. Bovine tuberculosis. Geneve: Office International des Épizooties, 1995. 11 p.( Manual Amendment 2).

KANDUMA, E.; MCHUGH, T. D.; GILLESPIE, S. H. A review. Molecular methods for Mycobacterium tuberculosis strain typing: a users guide. Journal of Applied Microbiology, v. 94, p. 781-791, 2003.

KANTOR, I.N. Bacteriología de la tuberculosis humana y animal. Martinez: OPAS/OMS.1979. 63 p. (Nota técnica n.11).

KANTOR, I.N. Situación de la tuberculosis bovina en América Latina y el Caribe. Martinez: OPAS/OMS,1988. 23 p. (Nota técnica n.8).

KANTOR, I.N.; RITACCO, V. Bovine tuberculosis in Latin America and Caribbean: current status, control and eradication programs. Veterinary Microbiology, v. 40, n. 1-2, p. 5-14, 1994.

KLASTER, P. R.; KUIJPER, S.; VAN INGEN, C. W.; KOLK, A. H. J. Stabilized, freezedried PCR mix for detection of mycobacteria. Journal of Clinical Microbiology, v. 36, n. 6, p.1798-1800, 1998.

KLEEBERG, H. H. Tuberculosis humana de origen bovino y salud pública. Revue Scientifique et Techiique International Office Epizootics, v. 3, p. 55-76, 1984. 
KOCAGOZ, T; YILMAZ, E.; OZKARA, S.; KOCAGOZ, S.; HAYRAN, M; SACHEDEVA, M.; CHAMBERS, H. F. Detection of Mycobacterium tuberculosis in sputum samples by polimerase chain reaction using simplified procedure. Journal of Clinical Microbiology, v. 31, n. 6, p. 1435-1438, 1993.

KOCH, R. Die atiologie der Tuberkulose. Berliner Klinischen Wochenschrift, v. 15, p. 221$230,1882$.

LATINI, M. D. S; LATINI, O. A.; LOPEZ, M. L.; CECCONI, J. O. Tuberculosis bovina en seres humanos. Ver. Arg. Torax, v. 51, p. 13-16, 1990.

LEÃO, S. C; BRIONES, M. R S.; SIRCILI, M. P.; BALIAN, S. C.; MORAES, N.; FERREIRA NETO, J. S. Identification of two novel Mycobacterium avium allelic variants in pig and human isolates from Brazil by PCR-restriction enzyme analysis. Journal of Clinical Microbiology, v. 37, n. 8, p. 2592-2597, 1999.

LESLIE, I. W.; CORNER, L. A.; HERBERT, C. .; BURN, K. J.; MACCLANCY, B. N.; DONNELLY, W. J. C. Comparison of the specificity of human and bovine tuberculin PPD for testing cattle. Veterinary Records, v. 96, p. 332-341, 1975.

LIÉBANA, E.; ARANAZ, A.; DOMINGUEZ, L.; MATEOS, A.; GONZÁLES-

LLAMAZARES, O.; RODRIGUEZ-FERRI, E. F.; DOMINGO, M.; VIDAL, D.; COUSINS, D. The insertion element IS6110 is a useful tool for DNA fingerprinting of Mycobacterium bovis isolates from cattle and goats in Spain. Veterinary Microbiology, v. 54, p. 223-233, 1997.

LIÉBANA, E.; ARANAZ, A.; MATEOS, A.; VILAFRANCA, M.; GOMEZ-MAMPASO, E.; TERCERO, J. C; ALEMANY, J.; SUAREZ, G.; DOMINGO, M.; DOMINGUES, L. Simple and rapid detection of Mycobacterium tuberculosis complex organisms in bovine tissue samples by PCR. Journal of Clinical Microbiology, v. 33, n. 1, p. 33-36, 1995.

LONDON SCHOOL OF HYGIENNE \&TROPICAL MEDICINE. Tuberculosis: back to future. London: John Wiley, 1994. p.14-18. Third Annual Public Health Forum.

MAC FADDEN, J; KUNZE.Z; SEECHURN, P. DNA probes for detection and identification In:MAC FADDEN, J (Ed.) Molecular Biology of the Mycobacteria. London: Surrey University Press, 1990. p.14-18.

MARCONDES, A.G. Padronização da técnica de cultivo em camada delgada de agar middlebrook 7H11 para isolamento de Mycobacterium bovis. 2002. 115 f. Dissertação (Mestrado)-Faculdade de Medicina Veterinária e Zootecnia da Universidade de São Paulo, São Paulo, 2002. 
MILLER, J. M; JENNY, A. L.; PAYEUR, J. B. Polymerase chain reaction detection of Mycobacterium tuberculosis complex and Mycobacterium avium organisms in formalin-fixed tissues from culture-negative ruminants. Veterinary Microbiology, v. 87, p. 15-23, 2002.

MONAGHAN, M. L., DOHERTY, M. L.; COLLINS, J. D.; KAZDA, J. F.; QUINN, P. J. The tuberculin test. Veterinary Microbiology, v. 40, p. 111-124, 1994.

MORRIS, R. S.; PFEIFER, D.U.; JACKSON, R. The epidemiology of Mycobacterium bovis infection. Veterinary Microbiology, v. 40, n. 12, p.153-177, 1994.

NEILL, S. D.; POLLOCK, J. M.; BRYSON, D.B.; HANNA, J. Pathogenesis of Mycobacterium bovis infection in cattle. Veterinary Microbiology, v. 40, n. 1-2, p. 41-52, 1994.

O'REILLY, L. M.\& DABORN, C. J. The epidemiology of Mycobacterium bovis infections in animals and man: a review. Tuberculosis and Lung Disease, v. 76, p. 1-46, 1995.

Suplemento 1

ORGANIZACIÓN MUNDIAL DE LA SALUD. Situación de la tuberculosis bovina en las América. Washington, D.C., 1995. (RIMSA 9, Informativo 26).

PALOMINO, J. C; MARTIN, A.; PORTAELS, F. New methods for the diagnosis and drug resistance detection in mycobacteria. Recent Research Development Microbiology, n. 6, p. 297-318, 2002.

PAULA, A. Tuberculose: ontem, hoje e amanhã. Jornal Brasileiro de Medicina, v. 55, n. 1, p. 74-98, 1988.

PRITCHARD, D. G. A century of bovine tuberculosis 1888-1988: conquest and controversy. Journal of Comparative Pathology, v. 99, p. 356-397, 1988.

RIO DE JANEIRO, Secretária de estado de saúde.Educando para prevenir: tuberculose Disponível em: $<$ http://www.saude.rj.gov.br/Guia sus cidadao/pg 39.shtml $>$. Acesso em: 25 jan. 2004.

ROCHA, A.S.; BARRETO, A. M. W.; CAMPOS, C. E. D.; SILVA, M. V.; SAAD, M. H.; DEGRAVE, W. M., SUFFYS, P. N. Novel allelic variants of Mycobacteria isolated in Brazil as determined by PCT- restriction enzyme analysis of $h s p$ 65. Journal of Clinical

Microbiology, v. 4, n. 11, p. 4191-4196, 2002. 
RODRIGUEZ, J. G.; MEIJA, A.; DEL PORTILlO, P.; PATARROYO, M. E.; MURILLI, L. A. Species-specific identification of Mycobacterium bovis by PCR. Microbiology, v. 141, p. 2131-2136, 1995.

RODRIGUEZ, J. G; FISSANOTI, J. C; DEL PORTILLO, P.; PATARROYO, M. E.; ROMANO, M. I.; CATALDI, A. Amplification of 500 base pair fragment from cultured isolates of M. bovis. Journal of Clinical Microbiology, v. 37, n. 7, p. 233-2332, 1999.

ROMANO, M. I.; ALITO, A.; FISANOTTI, J.; BIGI, F.; KANTOR, I.; CICUTA, M. E.; CATALDI, A. Comparison of different genetic markers for epidemiology of bovine tuberculosis. Veterinary Microbiology, v. 50, p. 59-71, 1996.

RORING, S. HUGHES, M. S.; SKUCE, R. A.; NEILL, S. D. Simultaneous detection and strain differentiation of Mycobacterium bovis directly from bovine tissue specimens by spoligotyping. Veterinary Microbiology, v. 74, p. 227-236, 2000.

ROTHSCHILD, B. M.; MARTIN, L. D.; LEV, G., BERCOVIER, H.; BAR-GAL, G. K.; GREENBLATT, C.; DONOGHUE, H.; SPIGELMAN, M.; BRITTAIN, D. Mycobacterium tuberculosis complex DNA from an extinct bison dated 17,000 years before the present. Origins of Tuberculosis in North America. Clinical Infectious Diseases, v. 33, p. 305-311, 2001.

ROXO, E. Tuberculose In: GONÇALVES, C.A.; ROXO, E.; CALIL, E.M.B.; KOTAIT, I.; BALDASSI, L.; PORTUGAL, M.A.S.C.; LAUAR, N.M.; CALIL, R.M.; GIORGI, W. Zoonoses: doenças dos animais transmissíveis ao homem. São Paulo: CATI, 1995. p.115120.

ROXO, E. Tuberculose bovina: revisão. Arquivos do Instituto Biológico,S.Paulo, v. 63, n. 2, p. 91-97, 1996.

ROXO, E.; IKUNO, A. A.; FERREIRA, V. C. A.; HARAKAVA, R.; RUGGIERO, A. P. M.; VIALTA, A. Avaliação de diferentes protocolos de extração de DNA de Mycobacterium bovis a partir de leite. Arquivos do Instituto Biológico, São Paulo, v. 69, p. 46, 2002. Suplemento.

SAKAMOTO, S.M. Tipificação de Mycobacterium bovis por spoligotyping e por análise de número variável de repetições seriadas (VNTR). 2001. $38 \mathrm{f}$.. Tese (Doutorado) Faculdade de Medicina Veterinária e Zootecnia da Universidade de São Paulo, São Paulo, 2001.

SAKAMOTO, S. M.; HEINEMANN, M. B.; TELLES, M.A. S.; ROXO, E.; RICHTZENHAIN, L. J.; VASCONCELLOS, S. A.; FERREIRA NETO, J. S. Detecção e identificação de Mycobacterium bovis pela reação em cadeia da polimerase (PCR) Arquivos do Instituto Biológico, v. 66, n. 2, p. 44-58, 1999. 
SALES, M. P.U.; TAYLOR, G. M.; HUGHES, S.; YATES, M.; HEWINSON, G; YOUNG, D. B.; SHAW, R. J. Genetic diversity among Mycobacterium bovis isolates: a preliminary study of strains from animals and human sources. Journal of Clinical Microbiology, v. 39, n. 12, p. 4558-4562, 2001.

SINGH, S. P.; SALAMON, H; LAHTI C. J; FARID-MOYER, M.; SMALL, P. M.. Use of pulsed-field gel electrophoresis for molecular epidemiologic and population genetic studies of Mycobacterium tuberculosis. Journal of Clinical Microbiology, v. 37, n. 6, p. 1927-31, 1999.

SJÖBRING, U.; MECKLENBURG, M.; ANDERSEN, A. B.; MIÖRNER, H. Polymerase chain reaction for detection of Mycobacterium tuberculosis. Journal of Clinical

Microbiology, v. 28, n. 10, p. 2200-2204, 1990.

SOLA, C.; RASTOGI, N; GUTIERREZ, M. C.; VICENT, V.; BROSCH, R.; PARSONS, L. Mycobacterium africanum subtype II (UgandaI e UgandaII) a genetically well-defined subspecies of the Mycobacterium tuberculosis complex? Journal of Clinical Microbiology, v. 41, n. 3, p. 1345-1348, 2003.

SOUZA, J. W. M. Tuberculose. Disponível em:

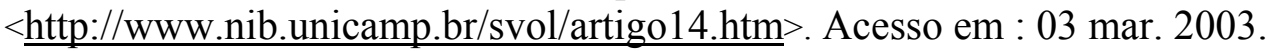

SREEVATSAN, S.; BOOKOUT, J. B.; RINGPIS, F. M.; MOGAZEH, S. L.; KREISWIRTH, B. M.; POTTATHIL, R. R.; BARATHUR, R. R. Comparative evaluation of a cleavase fragment lengh polimorphism with PCR-SSCP and PCR-RFLP to detect antimicrobial agent resistance in Mycobacterium tuberculosis. Molecular Diagnostic, v. 3, p. 81-91, 1998.

SUCCI, R. C. M. Tuberculose. Clínica Pediátrica, v. 2, n. 2, p. 30 -38, 1976.

TAYLOR, T. B.; PATTERSON C.; HALE Y.; SAFRANEK W. W. Routine use of PCRrestriction fragment length polymorphism analysis for identification of mycobacteria growing in liquid media. Journal of Clinical Microbiology, v. 35, n. 1, p. 79-85, 1997.

TAYLOR, J. M.; HUGHES,M. S.; SKUCE, R. A.; NEILL, S. D. Detection of Mycobacterium bovis in bovine clinical specimens using real-time fluorescence and fluorescence resonance energy transfer probe rapid-cycle PCR. Journal of Clinical Microbiology, v. 39, n. 4, p. 1272-1278, 2001.

TELENTI, A.; MARCHESI, F.; BALZ, M.; BALLY, F.; BOTTGER, E.; BODMER, T. Rapid identification of mycobacteria to the species level by polymerase chain reaction and restriction enzyme analysis. Journal of Clinical Microbiology, v. 31, n. 2, p. 175-178, 1993. 
TÖRNING, K. Bovine Tuberculosis: with a case report and some remarks. Diseases of the Chest, v. 47, p. 241-246, 1965.

USABIAGA, J. Brucelosis y tuberculosis bovina: ¿control o eliminación? São Paulo: OMS, 2001. (RIMSA 12/15).

VITALE, F.; CAPRA, G.; MAXIA, L.; REALE, S.; VESCO, G.; CARACAPPA, S. Detection of Mycobacterium tuberculosis complex in cattle by PCR using milk, lymph node aspirates and nasal swabs. Journal of Clinical Microbiology, v. 36, n. 4, p. 1050-1055, 1998.

WARDS, B. J.; COLLINS, D. M.; LISLE, G. W. Detection of Mycobacterium bovis in tissues by polymerase chain reaction. Veterinary Microbiology, v. 43, p. 227-240, 1995.

WEIL, A., PLIKAYTIS, B. B; BUTLER, C. L.; WOODLEY, C. L.; SHINNICK, T. M. The mtp40 gene is not present in all strains of Mycobacterium tuberculosis. Journal of Clinical Microbiology , v. 34, n. 9, p. 2309-2311, 1996.

WORLD HEALTH ORGANIZATION REGIONAL OFFICE FOR EUROPE, Tb deaths increasing in eastern europe 2002. Disponível em: $<$ http://www.who.int/archives/inf-pr1994/pr94-48.html>. Acesso em :21 jan. 2004.

WORLD HEALTH ORGANIZATION. Report of the WHO meeting on zoonotic tuberculosis (Mycobacterium bovis) with the participation of FAO. Geneve, 27 pag., 1993.

WORLD HEALTH ORGANIZATION. Tuberculosis. Fact Sheet No 104. Disponível em $<$ http://www.who.int/mediacentre/factsheets/who104/en/>. Acesso em: 21 jan. 2004.

WORLD HEALTH ORGANIZATION. Zoonotic tuberculosis (Mycobacterium bovis) memorandum from a WHO meeting with the participation of FAO. Bulletin of World Health Organization, v. 72, p. 851-857, 1994.

YEBOAH-MANU, D.; YATES, M.D.; WILSON, S.M. Application of a simple multiplex PCR to aid in routine work of the mycobacterium reference laboratory. Journal of Clinical Microbiology, v. 39, n. 11, p. 4166-4168, 2001.

ZANDEN, A.G.M. Spoligotyping, a tool in epidemiology, diagnosis and control of tuberculosis. Nijmegen, 2002, p. 12-45. Tese (Doutorado) Katholieke Universiteit Nijmegen. 
ZANINI, M. S.; MOREIRA, E. C; LOPES, M. T. P; OLIVEIRA, R. S.; LEÃO, S. C.; FIORAVANTI, R. L.; ROXO, E.; ZUMARRAGA, M.; ROMANO, M. I.; CATALDI, A.; SALAS, C. E. Mycobacterium bovis: polymerase chain reaction identification in bovine lymph node biopsies and genotyping in isolates from southeast Brazil by spoligotyping and restriction fragment length polymorphism. Memórias do Instituto Oswaldo Cruz, v. 96, n. 6, p. 809-813, 2001.

ZUMARRAGA, M.; MARTÍN, C.; SAMPER,S.; ALITO, A.; LATINI, O.; BIGI, F.; ROXO, E.; CICUTA, M. E.; ERRICO, F.; RAMO, M.C.; CATALDI, A.; SOOLIGEN, D.; ROMANO, M.I. Usefulness of Spoligotyping in Molecular Epidemiology of Mycobacterium bovis-related infections in South America. Journal of Clinical Microbiology, v. 37, n. 2, p. 296-303, 1999. 